\title{
The performance of private companies in China before and during the global financial crisis: firms' characteristics and entrepreneurs' attributes
}

\author{
Andrea Fracasso $^{1}\left[\right.$. Kun Jiang ${ }^{2}$
}

Received: 18 July 2020 / Accepted: 13 April 2021 / Published online: 10 May 2021

(c) The Author(s) 2021

\begin{abstract}
This work sheds light on how firm- and entrepreneur-specific attributes covariate with Chinese private firms' growth rates before and during the global financial crisis. In order to do so, we exploit the exceptional presence of data regarding the firms' sales over the previous three years in the 2010 China Private Enterprises Survey. Firms run by entrepreneurs with a high level of education and a positive subjective perception of their economic and social status tend to grow more in both periods. The age and the gender of the entrepreneurs, on the contrary, are not associated with different growth performances. As shown in the literature, companies that are smaller, more productive and have higher capital at start-up perform better in both periods. Notably, the relationship between firm growth rates and other relevant factors changes between 2007/2008 and 2008/2009: privatized companies outperform the others before the crisis, whereas joint-stock enterprises and companies with articulated systems of corporate governance do better in the crisis period. These and other novel results contribute to the understanding of the heterogeneous performances of the private firms in China and of the evolution of entrepreneurship during its transition toward a market-oriented economy.
\end{abstract}

Keywords China $\cdot$ Entrepreneurship $\cdot$ Firm growth $\cdot$ Global financial crisis

JEL classification $\mathrm{L} 25 \cdot \mathrm{L} 21 \cdot \mathrm{L} 26$

Andrea Fracasso

andrea.fracasso@unitn.it

1 Department of Economics and Management and the School of International Studies, University of Trento, Trento, Italy

2 Nottingham University Business School, Nottingham, UK 


\section{Introduction}

Firm heterogeneity is a well-known feature of the economy, and firm growth variation is often discussed in the economic, management and business literature. As pointed out by Coad (2009), Coad and Holzl (2012) and Ipinnaiye et al. (2017), heterogeneity in firm growth can be accounted for by a number of factors: firm-specific features (e.g., corporate governance, age, size), firms' strategies and decisions (e.g., innovation, export, investment, financing) and entrepreneurs' traits (e.g., age, experience, beliefs, education, optimism). The impact of these factors, in turn, has been shown to vary considerably over the business cycle and in particular during and after economic crises (see, for instance, Cowling et al. 2015, 2018; Fort et al. 2013; Peric and Vitezic 2016; Saridakis 2012), most likely because the features that boost growth in good times are different from those needed to weather negative shocks. In the attempt to draw novel information about the development of China's private firms in the face of the challenges posed by the Global Financial Crisis (GFC), the China Private Enterprises Survey (CPES) was modified in 2010 so as to gather information about the evolution of firm sales and profits over the crisis period, that is between 2007 and 2009. By exploiting this special feature of the 2010 wave of this well-known and representative survey for the first time, this work aims at improving our understanding of the heterogeneous impact of the GFC on the determinants of firm growth across Chinese private enterprises.

This paper contributes to the literature on heterogeneous firm growth in that it offers novel empirical evidence about how various firm- and entrepreneur-level factors determine the growth of the Chinese private sector around the GFC. China is interesting to study for at least two reasons. First, firm growth rates in China have always been very heterogeneous, even within industries and regional areas; second, the GFC considerably affected the Chinese economy, shifting its growth paradigm from an export-led model to a domestic demand-driven pattern (for a discussion, see Benini and Liping 2013; Bonatti and Fracasso 2010, 2013; Cai et al. 2010; Fan et al. 2013; Lardy 2011; Wong 2011; Zheng et al. 2009). ${ }^{1}$ Understanding how the GFC affected Chinese private companies, however, is also relevant to those interested in economies in transition as, at the time of the crisis, China was rapidly progressing in its transformation toward a market-oriented economy. Accordingly, our analysis contributes to the limited research on the heterogeneous growth performances of private companies in economies in transition (see Botta 2020; He et al. 2019; Kolasa et al. 2010; McMillan and Woodruff 2002, for a discussion). In particular, as entrepreneurship plays an important role in the process of structural change and innovation (Vivarelli 2013, 2016), China represents an interesting laboratory given the massive privatization spree that started in the early 2000s. While the CPES contains information about firm-specific features, firms' strategies and entrepreneurs'

\footnotetext{
1 This paradigm shift was reinforced by a gigantic stimulus package implemented by the authorities to support the economy. This package included an increase in government spending of 4 trillion RMB over 2009 and 2010, in addition to very generous credit policies (see Bai et al. 2016; Cong et al. 2019; Wen and $\mathrm{Wu} 2019$, for a discussion of the plan).
} 
traits, our empirical investigation addresses a number of relevant features of Chinese private companies that balance sheet data alone would not allow us to investigate (more on this below).

This analysis provides evidence confirming some previous findings, that is that firm size and productivity are, respectively, negatively and positively correlated with firm growth. Moreover, the company's performance appears to increase with the level of education of the entrepreneur in both periods. We found that while the age and the gender of the entrepreneur are not correlated with firm growth rates within the two years we investigated, the companies whose entrepreneurs have a higher socioeconomic status did grow relatively quickly within the same period. Exporting firms grew less than the others in the second period, most probably because of the sharp contraction in external demand due to the GFC. On the contrary, in this difficult period of time, the companies investeing in knowledge accumulation did record better performances than the other firms.

The enterprises whose entrepreneurs served as the CEO grew more than the others in 2008/2009, as did the companies with a board of directors and/or a board of shareholders. These findings suggest that the presence of an articulated system of corporate governance with a direct engagement of the entrepreneur at the top created an advantage for enterprises during the GFC. Similarly, joint-stock companies (including almost all Sino-foreign joint venture companies at the time) exhibited higher growth rates than other Chinese private companies during the crisis period, whereas privatized companies expanded relatively more only in the year before the crisis. Our investigation reveals that private companies with more credit to start increased their sales relatively more during the GFC, probably because they benefited from internal resources and continued to have preferential access to external financing from banks under the (indirect) control of the Chinese authorities.

This paper relates to various strands of literature on firm growth and entrepreneurship, and bridges them while providing novel empirical evidence on the Chinese economy at the time of the GFC.

The first line of research this paper relates to are those works investigating the heterogeneous growth of Chinese companies. Most of the existing studies explore the issue by analyzing the Chinese Annual Survey of Industrial Production database (see, among others, Bin et al. 2020; Chen et al. 2011; Guariglia et al. 2011; Ding et al. 2016; Moschella et al. 2019; Yu et al. 2017). This is a survey covering State-owned companies and the private industrial firms with sales above 5 million RMB. Although rich in terms of information, this database provides no information on entrepreneurs' characteristics or on small firms. Accordingly, the relationship between the entrepreneurs' traits and the growth of their companies in China has not been explored using the Survey of Industrial Production database. To the best of our knowledge, only Elston et al. (2016) assess empirically the relationship between firm growth and entrepreneurs' characteristics in China, but he exploits an ad hoc survey covering exclusively micro-firms (up to 30 employees) and involving only a few (260) private entrepreneurs located in only five cities in China. Accordingly, it is unclear whether his results are generalizable. As the CPES includes a representative sample of private companies spread across all Chinese provinces and all industries, our work makes it possible to draw more general conclusions on the impact of 
entrepreneurs' traits and companies' characteristics on the growth of Chinese private firms.

A second line of research that this work relates to regards the study of entrepreneurship in China. While there are plenty of contributions on the evolution of entrepreneurship in the country, ${ }^{2}$ analysis on the relationship between entrepreneurs' characteristics and firm growth is still limited. Among the articles focusing on China, Djankov et al. (2006) offer one of the first small-sample (seven cities, three provinces) analyses on the individual characteristics of the Chinese entrepreneurs, Yueh (2009) investigates the traits of self-employed entrepreneurs in urban areas, and Zheng and Zhao (2017) study the determinants of local clusters of entrepreneurship in China. As anticipated, none of these works explore how Chinese firms' growth rates vary with the entrepreneurs' traits. This is a promising avenue of research because several contributions have shown that different entrepreneurs' attributes are associated with heterogeneity in business practices and in firms' activities. According to Curtis (2016), for instance, the distribution of managerial talent determines the way Chinese private companies deal with constraints affecting (small) private firms. Liu et al. (2014) show that the companies whose entrepreneurs have previous work experience in multinational firms outperform those run by entrepreneurs without such experience. Marquis and Qiao (2020) find evidence that a founder's communist ideological imprinting influences the company's internationalization strategies, whereas Lu and Wu (2020) show that an entrepreneur's religious beliefs are associated with diverse networking strategies. Finally, the importance of the entrepreneurs' political affiliation and connections is discussed at length by Dong et al. (2016), Guo et al. (2014) and Li et al. (2008), and others.

Our study refers to a third branch of the literature showing that business cycle fluctuations and economic crises have a different impact on heterogeneous firms (Saridakis 2012). Moscarini and Postel-Vinay (2012) suggest that the negative relationship between firm size and growth performance becomes stronger, in absolute value, during crisis times. Kolasa et al. (2010) show that various firm characteristics account for the heterogeneous response of Polish firms in the face of the GFC in 2008/2009. Investigating the UK, Cowling et al. (2015) find that only half of the SMEs experienced a serious fall in sales after the GFC, and Fort et al. (2013) show that young and small businesses tend to exhibit different cyclical dynamics with respect to the others, with the former suffering more during the GFC. Smallbone et al. (2012), on the contrary, find that the performances of the small companies in the UK and New Zealand are not significantly different in the aftermath of the economic crises. Focusing on the determinants that improve the firms' capacity to weather a crisis, Peric and Vitezic (2016) conclude that firm growth was not significantly related to companies' size before the GFC, but it was positively correlated with it during the crisis. Cowling et al. (2018) study the relationship between the entrepreneurs' experience and the performance of their SMEs in the UK after

\footnotetext{
${ }^{2}$ Expanding on the seminal work by Ahlstrom and Ding (2014), He et al. (2019) and Cumming et al. (2016) summarize and discuss the findings contained in two special issues on the evolution of entrepreneurship in China.
} 
the GFC and show that previous experiences did not help them to weather a crisis. Unsurprisingly, there are several studies focusing on the relationship between firm financing, investment and survival during major crises. Among these, Cowling et al. (2012) find that the demand for external finance by SMEs in the UK tends to change when the economy enters a recession. Lin and Chou (2015) show that the source of financing for Chinese companies did considerably change after the GFC. Bartz and Winkler (2016) assess the relative growth performance of German firms during the 2009 crisis and find that firm age exerts a different effect in normal times and in crisis periods, while firm size preserves a negative correlation with growth in both. Clarke et al. (2012) investigate the relationship between firm survival and the severity of financial constraints in Eastern Europe and Central Asia after the GFC, while Iwasaki (2014) explores a large-scale enterprise survey to examine the survival of Russian industrial firms before and after the GFC. Joe et al. (2019) examine the performance of Korean owner-managers and employed managers during the Asian financial crisis and the GFC, and find that owner-managers over-perform due to their superior investment decisions. Investment patterns during the GFC crisis are analyzed by Campello et al. (2010), who find that problems were more serious for credit-constrained firms. By focusing on entrepreneurs' traits and firms' characteristics around the GFC, our study bridges the research on the determinants of firm growth with the strand of the literature on the differentiated impact of economic crises and the business cycle fluctuations on firm performances.

The remainder of the article proceeds as follows. Section 2 introduces the theoretical background and the hypotheses (i.e., research questions) to test empirically, while Sect. 3 discusses the empirical framework. Section 4 provides information on the dataset and on the variables of interest, whereas the empirical findings are presented and discussed in Sect. 5. Section 6 is our conclusion.

\section{Theoretical background}

Several theoretical contributions in the fields of industrial economics, business, and management studies have shown that various characteristics of the firms along with entrepreneurs' traits may potentially have an impact on the performance of the companies. This work focuses on Chinese private companies in 2007-2009 to build on those insights and examines, first, what firm- and entrepreneur-specific covariates correlate with firm growth and, second, whether these relationships change with the onset of the GFC. In particular, we follow Ipinnaiye et al. (2017) and consider three groups of covariates that previous works found relevant to explain firm growth: firms' characteristics, entrepreneurs' traits, and firms' strategies and decisions.

As for the characteristics of the firm that covariate with growth, one has to consider firm size and firm age. Since the seminal work by Gibrat (1931), several studies have shown the existence of an inverse relationship between the initial size and the growth rate of the firm, and several explanations are compatible with this fact (Daunfeldt and Elert 2013; Neumark et al. 2011; Arkolakis et al. 2018). Companies that are more distant from the industry-specific "medium efficient size", for instance, need to expand faster so as to rapidly close their efficiency gap. Moreover, in highly 
competitive and innovative industries, where selection is tougher, the small-size firms that survive tend to exhibit higher growth rates. Firm age can affect the ability of a company to grow though various channels (Haltiwanger et al. 2013; Lawless 2014), and Vivarelli (2013) and Coad (2018) illustrate several mechanisms such as: learning theories; accumulation of routines; liabilities of newness, senescence and obsolescence; routinization and reputation building. As suggested by Coad and Holzl (2012) and Coad (2018) in their surveys of the empirical literature, any empirical analysis focusing on the covariates of firm growth has to consider both firm size and age simultaneously because these variables are correlated between them and negatively associated with firm growth. Moreover, size often operates as a mediating factor for the impact of age on firm performance.

Level of productivity is another interesting firm characteristic. Previous studies focusing on other countries have shown its relevance. Moreover, there is ample evidence in the literature that the progressive improvement in aggregate productivity in China was due to progress in allocative efficiency, which is associated with the faster growth of the more productive firms (Bin et al. 2018; Brandt et al. 2012; Chen et al. 2011; Curtis 2016). Furthermore, as shown by Guariglia et al. (2011), Moschella et al. (2019) and Yang and Tsou (2020), more productive firms in China tend to generate sufficient cash flow to finance investment and to grow at fast rates. To a certain extent, moreover, the level of productivity can be viewed as a proxy for the firm's ability to exploit growth opportunities. The last reason to include the level of productivity in the analysis has to do with its indirect effect on growth: as explained by Barba Navaretti et al. (2014), productivity may be a factor leading to self-selection, and it has to be controlled for in the specification.

We believe that it is also important to control for the size and composition of capital at the establishment of an enterprise for two reasons. First, the financial dimension of the firm at its foundation is a determinant of its future growth when credit constraints are binding (Carpenter and Petersen 2002; Joeveer 2013; Musso and Schiavo 2008), as this is the case for small private firms in China (Hericourt and Poncet 2009; Moschella et al. 2019; Poncet et al. 2010). ${ }^{3}$ Access to external finance is important for firms' post-entry growth in normal times and, as discussed at length in Introduction, some works have shown that the dependence on external financing may lead, in difficult times, to more severe constraints, larger underinvestment and, thus, slower growth. Second, as the size and composition of the financial resources provided by the entrepreneur may be correlated with his/her human capital and other individual characteristics (Cassar 2004; Colombo and Grilli 2010; Honjo 2021), the omission of a control for financial resources at the time of the establishment could affect the interpretation of the impact of the entrepreneur's attributes.

Following the literature, we consider some aspects of corporate governance as well. The presence of boards of directors and shareholders, as well as the appointment of external managers in family-run firms, can impact the business strategies

\footnotetext{
3 Private firms' access to external credit in China has been limited because State-owned enterprises have traditionally received a preferential treatment by the financial institutions, due to their connections with the Chinese Communist Party.
} 
and, in particular, the ability of the company to adapt to the GFC. Similarly, as we focus on private companies in a country transiting toward a market-oriented economy, it is important to take a firm's origin into account (Kung and Li 2007; Yusuf et al 2005; Song et al. 2011). Private companies that were previously State-owned or collectively owned enterprises may preserve business practices adopted before privatization and may therefore differ from new companies, foreign-owned firms and joint-stock enterprises (Chen et al. 2009). While we cannot differentiate among firms in terms of their ownership structure (as done for instance by Yang and Tsou 2020 and Ding et al. 2016) because our sample contains exclusively private companies, by looking at the firms' origin we aim to capture the role of past business practices and imprinting effects. The literature suggests that these aspects have been very important in China, as well as in other economies in transition (Marquis and Qiao 2020; Mathias et al. 2015; Milanov and Fernhaber 2009). Notably, the origin and the corporate governance of the firms may have different effects on their relative growth rates before and during the GFC because previous experiences and business practices may have different impacts in different economic conditions. Finally, we have to control for the fact that a few firms merged with other companies in 2008/2009, and their sales mechanically increased by a large extent due to the merge.

The main entrepreneur's traits that need to be considered in the investigation of the determinants of firm growth have been pointed out by previous studies. The age, the level of education and the gender of the entrepreneurs can impact on entrepreneurs' risk aversion, on their appraisal of external opportunities and on their ability to understand customers. These factors, in turn, influence firm growth. Barba Navaretti et al. (2014) find that higher firm growth rates are associated with younger CEOs. Gielnik et al. (2012) conclude that the heterogeneous focus on opportunities is a mediating factor in the negative relationship between age and growth, and Gielnik et al. (2017) find systematic differences in firm performance associated with managers' age. Education may impact on firm growth as well, as found, for instance, by Goedhuys and Sleuwaegen (2000) and Goedhuys and Sleuwaegen (2010) in their analyses on African companies. Unger et al. (2011) find a positive correlation between education and success, even though the relationship is mediated by a number of firm- and environment-specific factors. The effect of education, however, appears to be less relevant in developed countries because technical and industryspecific knowledge is typically more important in advanced countries. ${ }^{4}$ Fairlie and Robb (2009) discuss various reasons why gender is persistently correlated with differences in business success and firm growth. As noted by Lee and Marvel (2014), however, gender often fails to be a significant determinant of performance once firm resources, perceived support from the ecosystem, and other context-specific characteristics and mediating factors are controlled for. ${ }^{5}$

Various individual personality traits (such as personal motivation, proactivity, agreeableness, self-efficacy, emotional stability and fear of failure) have the

\footnotetext{
${ }^{4}$ We refer to Marvel et al. (2016) for a review of the literature on human capital and entrepreneurship.

${ }^{5}$ Poggesi et al. (2016) offer a recent review of the literature on entrepreneurship and gender.
} 
potential to influence entrepreneurial decisions, such as entry and exit (Caliendo et al. 2014; Frank et al. 2007; Rauch and Frese 2007), and venture growth (Baum and Locke 2004; Miao et al. 2017; Kerr et al. 2017; Zhao et al. 2010). ${ }^{6}$ In this article we analyze the entrepreneur's evaluation of her socioeconomic status by looking at a few CPES questions explored by Chen and Zhang (2017) and Liu et al. (2021): perceived status can be used either as a proxy of reputation, associated with greater external trustworthiness in business, or as a proxy of self-esteem and optimism that tend to be positively correlated with risk taking (Hirshleifer et al. 2012; Zhang and Cueto 2017). ${ }^{7}$ Another reason to consider status in the estimation is that entrepreneurs with high status tend to attract more valuable people in the firm, and motivate them better. The well-established moderating role of environmental factors on entrepreneurship (see, for instance, Boudreaux et al. 2019; Wennberg et al. 2013) is particularly relevant for China, where the transition toward a market-oriented economy has been associated with a positive transformation of the public perception of private entrepreneurs (Chen and Zhang 2017). For all these reasons, companies run by entrepreneurs with a high social status may exhibit better firm performances. Our analysis contributes to the literature in that no previous work has assessed the role that the perceived socioeconomic status of the entrepreneur has on the performance of private firms in China. It is more generally interesting because, as pointed out by Kerr et al. (2017), self-esteem is one of those personal traits for which the research is still limited also outside China.

Finally, firms may exhibit different growth trajectories because of specific business cultures and operating strategies, and this has to be taken into account, as suggested by Ipinnaiye et al. (2017). Available empirical evidence indicates that the internationalized firms tend to grow faster than the others (Grazzi and Moschella 2018; Sousa et al. 2012; Yang and Tsou 2020), often thanks to the process of learning-by-exporting. This is true also in China before the GFC, and Yang and Tsou (2020) show that export premia enhanced growth in companies of all sizes and ages. However, less is known about the crisis period, even though aggregate data suggest that export status fails to be associated with higher growth performances. Finally, the literature has shown that the accumulation of knowledge through Research and Development (R\&D) investment and workers' training may help firms' expansion, but the evidence on this relationship is not conclusive (Capasso et al. 2015; Di Cintio et al. 2017; Coad and Rao 2008; Deschryvere 2014; Freel 2000; Freel and Robson 2004; Geroski and Machin 1992; Hölzl 2009). Hence, in this work, we exploit the CPES data to investigate whether the firms that engaged in such activities during the GFC grew more than those that did not.

\footnotetext{
6 The works in this strand of the literature stem from the upper echelons theory by Hambrick and Mason (1984).

7 We refer to George et al. (2016) for an overview of the role of reputation and status in management.
} 


\section{Empirical specification}

To address the question of how firm growth covariates with firms' and entrepreneurs' characteristics before and during the GFC, we apply the empirical model commonly used in the literature on firm growth. The covariates that we introduce in our specification follow the theoretical considerations illustrated in the previous Section and depend also on the questions available in the CPES that we can use to build proxies of the relevant concepts.

In general, thus, our empirical specification looks as follows:

$$
\operatorname{growth}_{f, t}=\boldsymbol{\beta} \mathbf{X}_{f}+\boldsymbol{\phi} \mathbf{X}_{e}+\delta_{p}+\delta_{i}+\epsilon_{f, t}
$$

where the annual percentage growth rate for firm $f\left(\right.$ growth $\left._{f}\right)$ depends on unobserved effects at the provincial and industry level (respectively, $\delta_{p}$ and $\delta_{i}$ ), as well as a number of covariates (more in the following Section) that can capture firm characteristics and strategies $\left(\mathbf{X}_{f}\right)$ and entrepreneur's traits $\left(\mathbf{X}_{e}\right)$.

As we discuss in Sect. 4, in the 2010 wave of the CPES, the entrepreneurs were asked about the sales, profits and taxes of their companies for the years 2007, 2008 and 2009. They were also asked to answer other questions about themselves and their companies at one point in time (e.g., at the establishment, in $2009, \ldots$..). The structure of the questionnaire allows us to calculate two growth rates (2007/2008 and 2008/2009) for each company in the sample, but we cannot build a panel dataset because for all the other variables there is only one observation. It follows that, in considering the structure of the dataset and the possible existence of a structural break around the GFC, it makes sense to run two cross-sectional regressions: one explores the determinants of the heterogeneous growth rates observed between 2007 and 2008, and the other looks at the data between 2008 and 2009.

We introduce the industry and provincial effects $\left(\delta_{i}\right.$ and $\left.\delta_{p}\right)$ to control for the unobserved idiosyncratic factors that Poncet et al. (2010) and Shi and Wu (2017), among others, have shown to be important to explain the performance of Chinese firms. The literature has found evidence of the existence of a relationship between the uneven spatial distribution of entrepreneurship and the dispersion of various local factors (Elston and Weidinger 2019; He et al. 2019; Yang and Tsou 2020; Zhu et al. 2019). ${ }^{8}$ Either random or fixed effects could be used to account for this kind of unobserved heterogeneity. The fixed effects estimator ensures unbiased estimates, but this comes at the cost of renouncing to analyze industrial and provincial variables. ${ }^{9}$ Hence, we adopt a statistical methodology to select between alternative specifications and perform the Hausman test for the growth rates in 2007/2008

\footnotetext{
${ }^{8}$ Notably, similar considerations are valid for other countries too, as shown by Barbosa and Eiriz (2011).

${ }^{9}$ Different research questions need different specifications. For instance, Ge et al. (2017) are interested in the effects of the local environment on the entrepreneurs' political connections, and they can include only industry fixed effects because they need to encompass a number of regional variables in the empirical specification. Ma et al. (2015) explore the impact of both industry- and regional-related variables on the firms' decision to become members of the All-China Federation of Industry and Commerce; thus, they cannot incorporate any fixed effects.
} 
and in 2008/2009. As the data reject the null hypothesis with the random effects model, we opt for including both industry and provincial fixed effects, in line with previous studies in the literature (among those using a single wave of the CPES, we recall Degryse et al. 2016). ${ }^{10}$ As anticipated above, this specification prevents us from exploring the role of industry- and location-specific conditions, such as those associated with the Chinese stimulus plan after the emergence of the GFC or with agglomeration economies and spillovers effects. The inclusion of these fixed effects is necessary, however, to prevent that unobserved heterogeneity at the industry and provincial level might bias the estimates of the firm- and entrepreneur-specific parameters of interest.

Before describing the variables that we use to explore the theoretical aspects discussed in Sect. 2, we shall introduce the CPES and the peculiar characteristics of its 2010 wave that are exploited, for the first time, in our analysis.

\section{The survey and the variables of interest}

\subsection{The China Private Enterprises Survey}

The China Private Enterprises Survey, built through face-to-face interviews with Chinese entrepreneurs, is based on questionnaires and sampling schemes designed by a research team made of economists and sociologists from the Chinese Academy of Social Sciences and several Chinese universities. ${ }^{11}$

Two important features distinguish this from other surveys providing microdata on the development of Chinese private enterprises and their entrepreneurs. First, it is one of the longest-running large-scale (nationwide and stratified) surveys of private enterprises in China, having started in the mid-1990s and repeating regularly every other year. Second, to ensure that it remains representative of the population of registered private firms at the national level, the entrepreneurs are resampled systematically at each wave through a multi-stage stratified random sampling procedure, including stratifications on location, industry, stage of economic development and distribution in urban and rural areas within each location (city/county). ${ }^{12}$ While larger datasets like the Chinese Annual Survey of Industrial Production database contain exclusively balance sheet data for relatively large firms, the CPES considers also entrepreneurs' characteristics and includes companies of any size.

\footnotetext{
10 The details of the tests are available upon request.

11 The CPES has been conducted by the Privately Owned Enterprises Research Project Team that includes the All-China Federation of Industry and Commerce, the State Administration for Market Regulation, the Chinese Academy of Social Sciences, the China Society of Private Economy, and the United Front Work Department of the CCP. Although strongly supported by the authorities, the data collection is not part of a government survey, and this reduces concerns of under-reporting for fiscal reasons.

12 Notably, the CPES' original sample frame was a modified version of the official frame used by the China State Bureau of Statistics for its annual data collection. More information on the characteristics of the sampling procedures and on the various waves of the Survey is provided by Chen et al. (2019), who illustrate the wide use of the Survey among Chinese and international scholars.
} 
Because of CPES' unique features, various waves have been analyzed by several scholars interested in investigating entrepreneurs and private companies in China. Among the cross-sectional studies using a single wave of the Survey ${ }^{13}$, we recall contributions by Chong et al. (2013), Degryse et al. (2016), Du et al. (2015), Ge et al. (2017), Lu and Tao (2009), Lu and Wu (2020), Ma et al. (2015) and Zhao and Lu (2016). Degryse et al. (2016) assess the impact of formal and informal finance on firm growth by exploring the 2006 wave; the same wave is studied also by Chong et al. (2013) who investigate the relationship between local concentration of banks and firms' financing constraints. Using the 2010 wave, Lu and Wu (2020) explore the impact of the entrepreneurs' religious beliefs on their activities, and $\mathrm{Ma}$ et al. (2015) assess whether Chinese entrepreneurs in 2012 benefited from joining the government-controlled business association to obtain formal political identity. Analyzing the 2002 wave of CPES, Lu and Tao (2009) show that weaker contract enforcement in China was associated with a higher degree of family control of business. Multiple waves, pooled into repeated cross sections, have been investigated by Chen and Zhang (2017), Guo et al. (2014), Li et al. (2008) and Zhou (2013), in order to understand the implications of the entrepreneurs' political connections on the activities of their companies. ${ }^{14}$

The 2010 wave of the CPES differs from the other waves in that the respondents were asked to provide information on the sales (as well as profits and taxes) recorded by the company in the three (rather than the usual two) years before the survey (namely, 2007, 2008 and 2009). This feature of the 2010 questionnaire was added in order to learn about the performance of the private companies during the GFC, and it allows us to calculate two annual growth rates (one for 2007/2008 and one for 2008/2009) for each company that remained active between 2007 and 2010. All the other questions in the Survey refer to one period only, typically either at the time of the establishment (e.g., capital provided, previous legal status) or for the year 2009 (e.g., exporting status, levies and expenses paid, investment in pollution control, participation in a merger). Similarly, all the questions about the entrepreneurs' traits regard either their past (e.g., education, work experience) or the previous year (e.g., self-perception, affiliation to the Chinese Communist Party). This setup makes it impossible to build a longitudinal and representative panel dataset with the CPES data, but the availability of two growth rates per entrepreneur-firm allows us to track the companies in the years around the GFC by means of two cross-sectional estimations.

As mentioned above, a number of scholars have pooled various cross sections of the CPES to investigate a number of research questions. This pooling approach would have been unwarranted in our case. First, it would have forced us to use information for a timeline far from the height of the GFC. Second, it would have raised

\footnotetext{
13 According to Chen et al. (2019), from 1993 to 2016, 147 works adopted one year's cross-sectional data from CPES, accounting for $70 \%$ of the total works using the Survey.

14 Liu et al. (2014) pool the 2000, 2002 and 2004 waves to analyze the impact of the entrepreneurs' work experience in multinational companies on the return-on-equity of the private firms in which they operated at the time of the interview. Liu et al. (2021) explore how firms' CSR practices covariate with the social status of their entrepreneurs.
} 
the problem of distinguishing the impact of sampling issues (as the firms in the sample change from wave to wave) from the actual variation in the way the covariates of interest affect firm growth. Third, pooling various CPES waves to study the impact of the GFC would have been controversial: the possible presence of a structural break is exactly why we expect that the correlation between the covariates and the growth rates changes over time.

The 2010 edition of the CPES involves more than 4500 firm-entrepreneur dyads located in 158 cities across all the 31 Chinese provinces. This covers about $0.1 \%$ of all the private firms in China across 15 industries. Notably, the sample does not account only for the medium- and large-sized companies, but it includes also household enterprises and small firms. Our analysis is conducted on a slightly smaller sample of companies that we obtained after a careful selection of respondents. More precisely, we discarded information for the entrepreneurs who did not provide internally consistent answers (i.e., whose qualitative assessments-in particular regarding the direction of change of certain variables - were at odds with the quantitative answers given to other questions). We also eliminated those firm-entrepreneur dyads for which the data were not available in every year of interest. This refinement of the sample leads to a $10 \%$ reduction in the number of units, but all provinces and economic sectors continue to be covered in the restricted sample, which consists of 3697 firm-entrepreneur dyads. The summary statistics of the variables used in this work on this sample, illustrated in next Sect. 4.2, can be found in Table 1.

\subsection{Variables of interest}

To address the question of how firm growth covariates with firms' and entrepreneurs' characteristics around the GFC, we calculated the annual percentage growth rate (growth) for the firms as the log difference of the sales between two consecutive years:

$$
\text { growth }_{i t}=\ln \text { Sales }_{i, t}-\ln \text { Sales }_{i, t-1}
$$

where Sales $_{i, t}$ stays for the nominal sales (in million Yuan) of firm $i$ at time $t$, where $t$ is 2008 in the pre-GFC period and 2009 in the second period. In order to avoid that the results are driven by outliers, we winsorized the top and bottom $1 \%$ of the distribution of the growth rates. In the literature, firm size and firm growth are measured alternatively in terms of sales, employment or assets. While these proxies are not identical and choosing one has inevitable implications on the interpretation of the empirical results, our reference to firm sales is driven by the lack of data on employment and assets in the years 2007 and 2008. As mentioned before, the 2010 wave of the CPES gathered information on the three years before the survey only for a very limited number of firm characteristics (i.e., sales, taxes and profits).

Model (1) provides for the growth of firm sales to be a function of several covariates. The matrices $\mathbf{X}_{f}$ and $\mathbf{X}_{e}$ include correlates spanning the features of the firms and the personal traits of the entrepreneurs. We chose what covariates to include in $\mathbf{X}_{f}$ and $\mathbf{X}_{e}$ based on theoretical motivations and on the empirical evidence discussed 
in Sect. 2. These variables also reflect the availability of information in the Survey that is suitable for building valid proxies of the concepts of interest.

In what follows, we present the covariates by starting with the firm-specific variables that will enter our baseline specification (3), used in the regressions for the years 2007/2008 and 2008/2009. The size of the firm at the beginning of the period of observation ( $\ln$ Sales $_{2007}$ ) is introduced to control for the usual growth advantage of the smaller firms; we measured it in natural logs of nominal sales in 2007. The firm's age (AgeFirm), that is the number of years since foundation (in logs), helps to capture the typically higher growth of firms at start-up and to limit the confounding effects between firm age and size. To include a measure of labor productivity, the variable LabProd is calculated as the logarithm of the ratio of sales over the employees in 2009, following Guariglia et al. (2011). Admittedly, a better measure of labor productivity would use output instead of sales and hours worked in place of employees; yet, as the CPES does not contain such information, we resorted to the closest available proxy. The financial dimension of the firm at its foundation (In Capital at setup) is calculated as the logarithm of the initial capital (in million yuan). This accounts for one fundamental aspect of the capital structure of the private firms: the availability of resources.

The main attributes of the entrepreneurs in the baseline specification (3) are: the dummy variable Gender, taking value one when the entrepreneur is male and 0 otherwise; the age of the entrepreneur, AgeEntrepreneur; the dummy variable HighEducation, taking value one when the entrepreneur achieved at least a Bachelor Degree and 0 otherwise.

Our baseline specification, thus, reads as follows:

$$
\begin{aligned}
\text { growth }_{f, t}= & \beta_{1} \text { In }_{\text {Sales }_{f, 2007}}+\beta_{2} \text { In Capital at setup } \\
& +\beta_{3} \text { AgeFirm }_{f}+ \\
& +\beta_{4} \text { Gender }_{e, f}+\beta_{5} \text { Higheducation }_{e f f}+\beta_{6} \text { AgeEntrepreneur }_{e f f}+ \\
& +\delta_{p}+\delta_{i}+\epsilon_{f, t} .
\end{aligned}
$$

where $e, f$ refers to an entrepreneur-firm dyad. With the introduction of these correlates, the sample is reduced further to 2737 valid observations for the two cross-sectional regressions where the dependent variables are the growth rates in 2007/2008 and in 2008/2009.

Subsequently, considering one additional variable at a time, we explore the impact of other firm characteristics that are potentially correlated with firm growth for the reasons illustrated in Sect. 2. First, we consider whether the company was a Stateowned or collectively owned company before becoming private, and the dummy Privatized takes value 1 if the enterprise stems from a privatization. We also verify whether the firm is a joint-stock company, and the dummy Joint - stock company takes value 1 if this is the case. ${ }^{15}$ We also control for the relevance of external credit in the firm's capital at the time of the establishment (Credit in setup funds, calculated as a ratio of external credit over total capital), as this can proxy for the ability

\footnotetext{
15 The share of privatized companies in our sample of 2737 firms is $15 \%$, equivalent to 423 companies. The share of joint-stock companies is similar as their number is equal to 441 .
} 
Table 1 Summary statistics over the entire sample

\begin{tabular}{|c|c|c|c|c|c|}
\hline Variable & Obs & Mean & $\mathrm{SD}$ & Min & Max \\
\hline Growth $_{08 / 09}$ & 3697 & 22.44416 & 84.21538 & -80.9524 & 666.1046 \\
\hline Growth $_{07 / 08}$ & 3697 & 36.22620 & 126.7738 & -76.0791 & 942.8571 \\
\hline ln Sales 2007 & 3697 & 6.510302 & 2.222293 & 0.405465 & 14.76606 \\
\hline ln Capital at setup & 3095 & 5.172705 & 1.744897 & 0 & 10.96822 \\
\hline Age Firm (log) & 3485 & 2.128239 & 0.497255 & 1.098612 & 3.258096 \\
\hline LabProd (log) & 3601 & 2.818814 & 1.486687 & -5.99147 & 11.33719 \\
\hline Gender & 3686 & 0.856213 & 0.350922 & 0 & 1 \\
\hline High education & 3630 & 0.896419 & 0.304759 & 0 & 1 \\
\hline Age Entrepreneur & 3661 & 46.50423 & 8.515354 & 19 & 93 \\
\hline Privatized & 3697 & 0.163917 & 0.370250 & 0 & 1 \\
\hline Joint-stock company & 3697 & 0.159589 & 0.366274 & 0 & 1 \\
\hline Merged 2008-2009 & 3697 & 0.034893 & 0.183534 & 0 & 1 \\
\hline Credit in setup funds & 3426 & 0.258027 & 0.437613 & 0 & 1 \\
\hline Board of Directors & 3697 & 0.486611 & 0.499888 & 0 & 1 \\
\hline Board of Shareholders & 3697 & 0.463890 & 0.498762 & 0 & 1 \\
\hline Export status 2009 & 3268 & 0.126989 & 0.333012 & 0 & 1 \\
\hline R\&D exp status 2009 & 3252 & 0.406519 & 0.491259 & 0 & 1 \\
\hline Training status 2009 & 3498 & 0.696398 & 0.459879 & 0 & 1 \\
\hline Subsidies status 2009 & 3476 & 0.249137 & 0.432576 & 0 & 1 \\
\hline Entrepreneur CEO & 3697 & 0.796051 & 0.402986 & 0 & 1 \\
\hline Perceived economic status & 3535 & 5.373409 & 1.857631 & 1 & 10 \\
\hline Perceived social status & 3535 & 5.383310 & 1.889687 & 1 & 10 \\
\hline
\end{tabular}

Summary statistics refer to the original sample once inconsistent respondents are eliminated

of the firm to access external financing. To account for corporate governance, which is potentially associated with the control on the company and its performance, we encompass two dummy variables: the variable Board of directors, which takes value 1 if the firm has a Board of Directors, and Board of shareholders, taking value 1 if a Board of Shareholders is present. ${ }^{16}$ Finally, we control for the possibility that the enterprise underwent a merger in 2008-2009 (the dummy Merged in 2008 - 09, taking value 1 if the private enterprise merged with others), as this could be mechanically associated with higher growth rates when the operation is carried out. ${ }^{17}$

As suggested by Ipinnaiye et al. (2017), the empirical analysis of the determinants of firm growth could benefit from the introduction of covariates that capture aspects of the firms' strategies. The features of the CPES questionnaire allow us to explore two aspects that, as discussed in Sect. 2, the literature has shown to be relevant. These are export capacity and accumulation of knowledge. Hence, we created

\footnotetext{
16 The share of companies with either one of the two Boards is about $41 \%$, whereas $29 \%$ of the firms have both Boards, and around $30 \%$ have none.

17 The number of mergers in the sample, e.g., 96, is relatively low.
} 
three dummy variables to capture the following situations in the year 2009. First, we look at whether the firm exported part of its production or not (Export status 2009), as done for instance by Moschella et al. (2019) and Kolasa et al. (2010). Second, we explore whether the firm invested in $R \& D$ or not ( $R \& D$ exp status 2009). Third, we look at whether it organized training activities for its employees or not (Training status 2009). We also check whether there is a growth differential in 2009 for the firms receiving State subsidies; for this, we introduce the dummy variable Subsidies status 2009. This extension has to be considered as a rough check given that the Chinese stimulus plan consisted mainly of public investment and favorable credit conditions, and not subsidies. Yet, it is appropriate to assess empirically whether there is any statistically significant difference in growth rates associated with the provision of State subsidies or not. Notably, these four variables can be used exclusively to investigate growth in the period 2008/2009, as the CPES does not provide information regarding the years 2007 and 2008. Given this, along with the fact that the introduction of these variables reduces the number of observations, we prefer to consider their inclusion as an extension. Moreover, as these variables risk being endogenous due to their timing, we distinguish them clearly from the baseline specification, and we interpret their estimated coefficients only in terms of statistical association with no reference to causation. The baseline specification is thus extended with the inclusion of firm-specific covariates (collected in the matrix $\mathbf{X} \mathbf{2}_{f}$ ) for the growth rates between 2008 and 2009.

Finally, we produce a battery of regressions with a view to considering the possible impact of other entrepreneurs' traits on the growth rates of their firms. First, as done by Bartz and Winkler (2016), we distinguish the firms where the entrepreneurs are the CEOs with the dummy variable CEOentrepreneur. Second, we consider the perceived economic and social status of the entrepreneur. Perceived socioeconomic status is an important individual dimension that might impact the selection of business opportunities and practices, in terms of risk taking and the like. More precisely, as observed by Liu et al. (2021), the Survey asked the entrepreneurs to express what they think about their economic and social positions in relative terms. Perceived social status in China depends on the level of social respect and on reputation, whereas perceived economic status is mainly associated with income and wealth: thus, these two dimensions are similar (and their correlation is 0.8 ), but not identical. Accordingly, we build two categorical variables (Perceived social status and Perceived economic status) on the basis of the answers given by the respondents in rating their economic and social status on a 10-point Likert scale; they vary from 1 (highest relative position) to 10 (lowest relative position). ${ }^{18}$ It is worth noticing that although the CPES does not allow us to build measures of self-efficacy (Bandura 1997; Poon et al. 2006) or overoptimism (Cieslik et al. 2018), the subjective evaluation of the entrepreneurs' status is highly informative. For instance, as suggested by Koryak et al. (2015), perceived social status may act as a proxy for a measure of

\footnotetext{
18 Only $5 \%$ of the respondents placed themselves in the highest and lowest positions, while half of them rated their status as between 5 and 6 . This suggests that individual self-assessment can be considered, at least, reasonable.
} 
self-esteem. Judge and Bono (2001) show that self-esteem is an important driver of risk taking and of performance in business. Moreover, if the subjective social status evaluation mirrors the actual reputation of the entrepreneur in society, this variable can be associated with the entrepreneur's ability to mobilize societal resources. This is most likely in a country like China where personal relations play a key role in business.

The baseline specification, extended to include additional covariates for firmspecific $\left(\mathbf{X} 2_{f}\right)$ and entrepreneur-specific $\left(\mathbf{X} 2_{e}\right)$ characteristics, therefore reads as follows:

$$
\begin{aligned}
\text { growth }_{f, t}= & \beta_{1} \text { In Sales }_{f, 2007}+\beta_{2} \text { In Capital at setup } \\
& +\beta_{3} \text { AgeFirm }_{f}+ \\
& +\beta_{4} \text { Gender }_{e, f}+\beta_{5} \text { Higheducation }_{e, f}+\beta_{6} \text { AgeEntrepreneur }_{e, f} \\
+ & \boldsymbol{\gamma} \mathbf{X} \mathbf{2}_{f}+\boldsymbol{\phi} \mathbf{X} \mathbf{2}_{e}+\delta_{p}+\delta_{i}+\epsilon_{f, t} .
\end{aligned}
$$

Before presenting the results of the estimations, we introduce a few summary statistics to provide a synthetic comparison of our data with the sample adopted by Elston et al. (2016), which is the most recent study about Chinese entrepreneurs and firm growth. The summary statistics of the firm- and entrepreneur-level characteristics, from the sample of 3697 firm-entrepreneur dyads whose responses are internally consistent, are reported in Table 1 . Only $14 \%$ of the respondents in our sample are female, in line with the value $12.6 \%$ in Elston et al. (2016). The average and mean age in our sample are about 46 years, only slightly higher than the 40 -year average value in Elston et al. (2016). Despite these similarities, the two datasets differ along a few dimensions. More than half of the firms in Elston et al. 2016' sample have between 2 and 5 employees, whereas more than half of the firm-entrepreneur dyads in our dataset refer to companies with more than 50 employees. This confirms that while the CPES covers all kinds of private companies, the survey used by Elston et al. (2016) and their analysis focus almost exclusively on micro-firms. The share of respondents who achieved a high level of education in our sample is around $10 \%$, which is larger than the share in Elston et al. (2016); this difference can be related to their focus on micro-firms as well, because these latter are often run by less educated (self-made) entrepreneurs.

\section{Empirical results}

We ran two separate cross-sectional estimations for the firm growth rates in the period before the GFC (2007/2008) and during the crisis (2008/2009). As was mentioned above, a longitudinal analysis cannot be performed with the available data, and we are specifically interested in revealing the different effects that some covariates might have exerted at the time of the crisis. Tables 2 and 3 report the estimation results for the growth rates of firm sales, respectively, in 2007/2008 and 2008/2009.

In the first part of each table, we introduce the estimated coefficients for the firm's characteristics in the baseline specification (3). The analysis reveals that, in both periods, firm growth is negatively related to the level of sales at the beginning 
of the period, in line with what is shown in the literature. Smaller firms continue to exhibit relatively higher growth rates, in the attempt to close their distance from minimum efficient scale. The coefficient for this variable, however, is reduced by two-thirds in the second period, in line with what is also found by Kolasa et al. (2010) for Polish firms during the GFC. This is possibly due to the fact that the GFC negatively affected firm growth rates across the board, but exerted a stronger impact on the smaller firms. As suggested by Peric and Vitezic (2016), larger firms manage to weather crises better than the small ones, and firms in China, where credit constraints and other frictions are more binding for the small private companies than in other countries, make no exception.

As to the estimated coefficient of In Capital at $\operatorname{setup}_{f}$, the analysis reveals that firm growth rates positively correlate with the size of capital at setup in both periods, consistently with the tenet that better capitalized start-ups do experience higher growth in the following years. This finding is in line with Huynh and Petrunia (2010), among others. The estimated coefficient is, however, smaller during the crisis period. This can be explained with the fact that the GFC in China is associated with a fall in international demand and a credit crunch, which reduce the correlation between current growth and the level of capital at the time of establishment. More important, as we shall discuss, is the composition of such capital, at least to the extent that this proxies for the ability of the firm to obtain external financing when needed.

The age of the firm does not appear to affect its growth. Despite the fact that in 2007/2008 the sign of the coefficient is negative (as in Barba Navaretti et al. 2014; Degryse et al. 2016; Nunes et al. 2013, among others) and it turns positive in $2008 / 2009$, neither of the estimates is significantly different from zero. This finding might seem at odds with the conclusions reached by those studies showing that firm age negatively correlates with firm employment growth (see, for instance, Haltiwanger et al. 2013; Lawless 2014). However, this result is in line with Bin et al. (2020), who find that firm age does correlate with employment growth, but not with sales growth in China. Indeed, heterogeneous developments in labor productivity may lead to divergent variations in sales and in employment. ${ }^{19}$ It is also important to recall that, as specified by Coad (2018), when size and age enter into the estimation, their coefficients capture only the direct, and not the overall, impact of these variables, as they are related. This implies that it is the direct effect of firm age on growth that is found insignificant, but one cannot rule out any indirect channels associated, for instance, with the mediating effect that age has on size.

Finally, consistent with theory and previous studies (Guariglia et al. 2011; Moschella et al. 2019; Yang and Tsou 2020; Yu et al. 2017), the more productive companies tend to grow faster than the others. Importantly, the estimated impact in the two periods is similar. As argued in Sect. 2, it is possible that labor productivity captures some more general features of the company, namely, its greater growth

\footnotetext{
19 The relationship between size, age and various measures of firm growth is complex and far from trivial, as shown, for instance, by Audretsch et al. (2014), Coad et al. (2016), Coad (2018), Cowling et al. (2018) and Leoncini et al. (2019).
} 
Table 2 Firm growth covariates, pre-GFC-2007/2008

\begin{tabular}{|c|c|c|c|c|c|c|c|}
\hline & (1) & (2) & (3) & (4) & (5) & (6) & (7) \\
\hline ln $\mathrm{Sales}_{2007}$ & $\begin{array}{l}-29.44^{* * *} \\
(3.631)\end{array}$ & $\begin{array}{l}-30.04^{* * *} \\
(3.732)\end{array}$ & $\begin{array}{l}-29.56^{* * *} \\
(3.634)\end{array}$ & $\begin{array}{l}-29.59^{* * *} \\
(3.650)\end{array}$ & $\begin{array}{l}-30.64^{* * *} \\
(3.849)\end{array}$ & $\begin{array}{l}-30.12^{* * *} \\
(3.730)\end{array}$ & $\begin{array}{l}-29.75^{\text {*** }} \\
(3.660)\end{array}$ \\
\hline $\begin{array}{l}\text { In Capital at } \\
\text { setup }\end{array}$ & $(2.263)$ & $(2.238)$ & $(2.252)$ & $14.99^{* * *}$ & $16.12^{* * *}$ & $(2.270)$ & $(2.224)$ \\
\hline AgeFirm & $\begin{array}{l}-9.359 \\
(5.787)\end{array}$ & $\begin{array}{l}-8.787 \\
(5.826)\end{array}$ & $\begin{array}{l}-9.608^{*} \\
(5.789)\end{array}$ & $\begin{array}{l}-9.411 \\
(5.784)\end{array}$ & $\begin{array}{l}-7.459 \\
(6.196)\end{array}$ & $\begin{array}{l}-9.190 \\
(5.791)\end{array}$ & $\begin{array}{l}-8.734 \\
(5.812)\end{array}$ \\
\hline LabProd & $\begin{array}{l}28.32^{* * *} \\
(3.880)\end{array}$ & $\begin{array}{l}28.86^{* * *} \\
(3.988)\end{array}$ & $\begin{array}{l}28.40^{* * *} \\
(3.883)\end{array}$ & $\begin{array}{l}28.46^{* * *} \\
(3.900)\end{array}$ & $\begin{array}{l}29.34^{* * *} \\
(4.056)\end{array}$ & $\begin{array}{l}28.69^{* * *} \\
(3.925)\end{array}$ & $\begin{array}{l}28.40^{* * *} \\
(3.882)\end{array}$ \\
\hline Gender & $\begin{array}{l}7.974 \\
(6.450)\end{array}$ & $\begin{array}{l}7.556 \\
(6.442)\end{array}$ & $\begin{array}{l}7.863 \\
(6.439)\end{array}$ & $\begin{array}{l}7.931 \\
(6.447)\end{array}$ & $\begin{array}{l}8.333 \\
(6.710)\end{array}$ & $\begin{array}{l}8.040 \\
(6.453)\end{array}$ & $\begin{array}{l}7.816 \\
(6.442)\end{array}$ \\
\hline HighEducation & $\begin{array}{l}14.84^{* *} \\
(7.047)\end{array}$ & $\begin{array}{l}14.91^{* *} \\
(7.043)\end{array}$ & $\begin{array}{l}14.54^{* *} \\
(7.048)\end{array}$ & $\begin{array}{l}14.74^{* *} \\
(7.043)\end{array}$ & $\begin{array}{l}14.84^{* *} \\
(7.248)\end{array}$ & $\begin{array}{l}13.98^{* *} \\
(7.077)\end{array}$ & $\begin{array}{l}14.74^{* *} \\
(7.046)\end{array}$ \\
\hline AgeEntrepreneur & $\begin{array}{l}-0.0947 \\
(0.300)\end{array}$ & $\begin{array}{l}-0.174 \\
(0.299)\end{array}$ & $\begin{array}{l}-0.0861 \\
(0.301)\end{array}$ & $\begin{array}{l}-0.0832 \\
(0.301)\end{array}$ & $\begin{array}{l}-0.216 \\
(0.319)\end{array}$ & $\begin{array}{l}-0.133 \\
(0.303)\end{array}$ & $\begin{array}{l}-0.108 \\
(0.301)\end{array}$ \\
\hline Privatized & & $\begin{array}{l}14.68^{*} \\
(7.488)\end{array}$ & & & & & \\
\hline $\begin{array}{r}\text { Joint-stock } \\
\text { company }\end{array}$ & & & $\begin{array}{l}6.316 \\
(5.873)\end{array}$ & & & & \\
\hline $\begin{array}{l}\text { Merged } \\
2008-2009\end{array}$ & & & & $\begin{array}{l}11.44 \\
(11.01)\end{array}$ & & & \\
\hline $\begin{array}{l}\text { Credit in setup } \\
\text { funds }\end{array}$ & & & & & $\begin{array}{l}-7.329 \\
(4.955)\end{array}$ & & \\
\hline $\begin{array}{l}\text { Board of direc- } \\
\text { tors }\end{array}$ & & & & & & $\begin{array}{l}8.459 \\
(5.520)\end{array}$ & \\
\hline $\begin{array}{l}\text { Board of share- } \\
\text { holders }\end{array}$ & & & & & & & $\begin{array}{l}8.771^{*} \\
(4.753)\end{array}$ \\
\hline Industry FE & YES & YES & YES & YES & YES & YES & YES \\
\hline Province FE & YES & YES & YES & YES & YES & YES & YES \\
\hline Observations & 2737 & 2737 & 2737 & 2737 & 2570 & 2737 & 2737 \\
\hline Adjusted $R^{2}$ & 0.110 & 0.111 & 0.110 & 0.110 & 0.113 & 0.111 & 0.111 \\
\hline
\end{tabular}

Independent variable: growth rate of sales in 2007/2008. Covariates in baseline specification (1): firm sales in 2007 (logs), value of equity at birth $(\log )$, age of the firm $(\log )$, labor productivity in 2009 (sales over employees); entrepreneurs' gender and high education dummies, age of entrepreneur. Results show the coefficients with heteroskedasticity-robust standard errors (in parenthesis): ${ }^{*}<0.1,{ }^{* *}<0.05$, $* * *<0.01$ 
Table 3 Firm growth covariates, during GFC-2008/2009

\begin{tabular}{|c|c|c|c|c|c|c|c|}
\hline & (1) & (2) & (3) & (4) & (5) & (6) & (7) \\
\hline ln Sales 2007 & $\begin{array}{l}-12.45^{* * *} \\
(1.733)\end{array}$ & $\begin{array}{l}-12.63^{* * *} \\
(1.752)\end{array}$ & $\begin{array}{l}-12.67^{* * *} \\
(1.741)\end{array}$ & $\begin{array}{l}-12.66^{* * *} \\
(1.758)\end{array}$ & $\begin{array}{l}-13.43^{* * *} \\
(1.822)\end{array}$ & $\begin{array}{l}-13.33^{* * *} \\
(1.792)\end{array}$ & $\begin{array}{l}-12.74^{* * *} \\
(1.744)\end{array}$ \\
\hline $\begin{array}{l}\text { In capital at } \\
\text { setup }\end{array}$ & $\begin{array}{l}4.309^{* * *} \\
(1.229)\end{array}$ & (1.238) & $(1.222)$ & (1.230) & (1.254) & $(1.252)$ & (1.228) \\
\hline AgeFirm & $\begin{array}{l}1.053 \\
(3.698)\end{array}$ & $\begin{array}{l}1.229 \\
(3.709)\end{array}$ & $\begin{array}{l}0.575 \\
(3.697)\end{array}$ & $\begin{array}{l}0.981 \\
(3.692)\end{array}$ & $\begin{array}{l}0.152 \\
(3.849)\end{array}$ & $\begin{array}{l}1.272 \\
(3.686)\end{array}$ & $\begin{array}{l}1.645 \\
(3.738)\end{array}$ \\
\hline LabProd & $\begin{array}{l}21.56^{* * *} \\
(2.576)\end{array}$ & $\begin{array}{l}21.73^{* * *} \\
(2.585)\end{array}$ & $\begin{array}{l}21.73^{* * *} \\
(2.573)\end{array}$ & $\begin{array}{l}21.76^{* * *} \\
(2.599)\end{array}$ & $\begin{array}{l}22.49^{* * *} \\
(2.685)\end{array}$ & $\begin{array}{l}22.04^{* * * *} \\
(2.590)\end{array}$ & $\begin{array}{l}21.63^{* * *} \\
(2.578)\end{array}$ \\
\hline Gender & $\begin{array}{l}0.235 \\
(4.742)\end{array}$ & $\begin{array}{l}0.106 \\
(4.749)\end{array}$ & $\begin{array}{l}0.0225 \\
(4.720)\end{array}$ & $\begin{array}{l}0.176 \\
(4.738)\end{array}$ & $\begin{array}{l}0.213 \\
(4.895)\end{array}$ & $\begin{array}{l}0.320 \\
(4.723)\end{array}$ & $\begin{array}{l}0.0851 \\
(4.735)\end{array}$ \\
\hline HighEducation & $\begin{array}{l}11.66^{* * *} \\
(4.095)\end{array}$ & $\begin{array}{l}11.68^{* * *} \\
(4.105)\end{array}$ & $\begin{array}{l}11.08^{* * *} \\
(4.077)\end{array}$ & $\begin{array}{l}11.52^{* * *} \\
(4.087)\end{array}$ & $\begin{array}{l}12.09^{* * * *} \\
(4.171)\end{array}$ & $\begin{array}{l}10.54^{* * *} \\
(4.059)\end{array}$ & $\begin{array}{l}11.57^{* * *} \\
(4.097)\end{array}$ \\
\hline AgeEntrepreneur & $\begin{array}{l}0.0107 \\
(0.200)\end{array}$ & $\begin{array}{l}-0.0136 \\
(0.203)\end{array}$ & $\begin{array}{l}0.0272 \\
(0.199)\end{array}$ & $\begin{array}{l}0.0266 \\
(0.200)\end{array}$ & $\begin{array}{l}0.125 \\
(0.205)\end{array}$ & $\begin{array}{l}-0.0387 \\
(0.197)\end{array}$ & $\begin{array}{l}-0.00147 \\
(0.200)\end{array}$ \\
\hline Privatized & & $\begin{array}{l}4.520 \\
(4.608)\end{array}$ & & & & & \\
\hline $\begin{array}{r}\text { Joint-stock } \\
\text { company }\end{array}$ & & & $\begin{array}{l}12.09^{* *} \\
(5.095)\end{array}$ & & & & \\
\hline $\begin{array}{l}\text { Merged in } \\
2008-2009\end{array}$ & & & & $\begin{array}{l}15.86 \\
(10.06)\end{array}$ & & & \\
\hline $\begin{array}{l}\text { Credit in setup } \\
\text { fund }\end{array}$ & & & & & $\begin{array}{l}6.616^{*} \\
(3.895)\end{array}$ & & \\
\hline $\begin{array}{l}\text { Board of direc- } \\
\text { tors }\end{array}$ & & & & & & $\begin{array}{l}10.96^{* * *} \\
(3.756)\end{array}$ & \\
\hline $\begin{array}{l}\text { Board of share- } \\
\text { holders }\end{array}$ & & & & & & & $\begin{array}{l}8.322^{* *} \\
(3.481)\end{array}$ \\
\hline Industry FE & YES & YES & YES & YES & YES & YES & YES \\
\hline Province FE & YES & YES & YES & YES & YES & YES & YES \\
\hline Observations & 2737 & 2737 & 2737 & 2737 & 2570 & 2737 & 2737 \\
\hline Adjusted $R^{2}$ & 0.098 & 0.098 & 0.100 & 0.099 & 0.102 & 0.101 & 0.100 \\
\hline
\end{tabular}

Independent variable: growth rate of sales in 2008/2009. Covariates in baseline specification (1): firm sales in 2007 (logs), value of equity at birth $(\log )$, age of the firm $(\log )$, labor productivity in 2009 (sales over employees); entrepreneurs' gender and high education dummies, age of entrepreneur. Results show the coefficients with heteroskedasticity-robust standard errors (in parenthesis): ${ }^{*}<0.1,{ }^{* *}<0.05$, $* * *<0.01$ 
potential and its ability to effectively use available resources, both in good and bad times. For instance, Moschella et al. (2019) find evidence that labor productivity relates to higher probabilities for Chinese firms to enjoy high-growth status.

The second part of the tables includes the estimated coefficients for the entrepreneurs' attributes in the baseline specification (3). As found by Elston et al. (2016), the gender of the entrepreneur is immaterial for the performance of the firm. ${ }^{20}$ Differently from Elston et al. (2016), we found that companies with highly educated entrepreneurs score higher growth performances in both periods. The estimated coefficients in the two years preserve a similar dimension too. Our interpretation of this result is that educated entrepreneurs manage to adapt better to external conditions, in line with Goedhuys and Sleuwaegen (2000, 2010) and Gielnik et al. (2017). The entrepreneurs' age, on the other hand, is not significantly associated with higher firm growth in either of the two periods, at variance with what found by Elston et al. (2016) for the micro-firms in China. ${ }^{21}$ As recently discussed by Zhao et al. (2021), since the entrepreneur's age works as a synthetic proxy for a broad constellation of age-related factors that can be controlled for only partially in empirical studies, one has to interpret its correlation with (alternative measures of) firm performance with caution. Indeed, the relationship between entrepreneurs' age and firm growth is still controversial: greater experience, better ability to recognise potential benefits from agglomeration (Zhang 2017) and networking (He et al. 2019) can be offset by declining abilities and lower focus on opportunities (Gielnik et al. 2017). The positive coefficient in the GFC period, although insignificant, is at least in line with the findings provided by Peric and Vitezic (2016), who found that the entrepreneurs with the highest human capital work in companies that perform better during recessions. Finally, one could interpret the estimates together and tentatively conclude that, in China, the entrepreneurs' education is a more important determinant of firm growth than his/her age because, in the early stages of the transition toward a market-oriented economy, personal general education is less strongly correlated with experience and other business-related attributes than it is in other countries.

In Tables 2 and 3, we explore also how additional firm characteristics correlate with firm growth. For the reasons explained in Sect. 2, we consider the current and legal status of the company, as well as the presence of a board of directors and of a board of shareholders (or lack thereof). When investigating the determinant of the firm growth rates in $2007 / 2008$, only two variables have statistically significant coefficients; they are Privatized and Board of shareholders. In normal times, thus, the Chinese companies that changed their status from State- and collectively owned to

\footnotetext{
20 This is not necessarily the case in other countries. Although focusing on firm strategies rather than on firm growth, Buratti et al. (2018) show that male and female entrepreneurs reacted differently during the crisis period in Italy.

21 Two explanations for the divergence in these results are the non-negligible differences in the two datasets and the absence of various firm's characteristics and fixed effects in Elston et al. (2016)'s empirical specifications. Moreover, while Elston et al. (2016) measure education with a categorical variable, taking values ranging from 1 to 7 , we create a dichotomous variable by splitting the entrepreneurs between more educated (i.e., with at least a Bachelor degree) and less educated ones. These different ways to capture education may contribute to our contrasting results.
} 
privately owned tend to exhibit higher growth than the others. This result is in line with what is found by Yang and Tsou (2020), and it can be interpreted in two ways: one, this is the product of selection effects in the privatization process (due to privatization of the companies with better growth opportunities); two, it reflects the fact that privatized companies have continued to enjoy a privileged position among the private firms by preserving favorable access to scarce resources and public demand. When focusing on the GFC period, however, the coefficient for the variable Privatized loses statistical significance. This suggests that the hypothesis that a privileged position during the GFC comes with pre-existing ties with the authorities is not supported by the data. On the contrary, it is the joint-stock companies that exhibit relatively stronger growth during the crisis. As several joint-stock companies are joint ventures involving foreign firms, it is likely that their faster growth rates are associated with the benefits stemming from international connections (i.e., knowledge diffusion, intra-firm/group demand, intra-firm/group financing and the like). This accords well with the results in Kolasa et al. (2010), who found that foreign ownership of Polish firms mitigated the contraction in sales during the GFC period. The presence of a board of directors and/or of a board of shareholders appears positively correlated with firm growth rates in both periods: the size of the coefficients is similar, even though their significance is higher in 2008/2009. ${ }^{22}$ It seems that a more developed structure of corporate governance did help the Chinese private companies to grow more, particularly during the crisis period. This is in line with He et al. (2015), who found a positive relationship between a firm's efficiency and good corporate governance in China. All in all, these results seem to support the hypothesis that the growth of a Chinese private company also depends on the kind of experience, resources and business practices that it can draw upon either from its own past (or from its entrepreneur's, as shown by Marquis and Qiao 2020; Mathias et al. 2015; Milanov and Fernhaber 2009) or from external sources (i.e., connected companies and members of boards). The relative importance of the different sources does vary a lot in normal times and in crisis periods. The relative importance of external credit in capital at the time of establishment is another covariate that positively correlates with firm growth only in the second period. Insofar as the share of external credit in total capital at the time of establishment is a proxy for the ability of the firm to obtain external financing, this variable may reflect the vantage position of those private companies that, during the credit crunch, could receive the financial resources needed to support their growth.

As suggested by Ipinnaiye et al. (2017), our analysis would benefit from the introduction of covariates capturing relevant aspects of the firm's strategy. In Table 4, we introduce three covariates capturing firms' strategies in 2009: exporting (Export status 2009), investment in R\&D (R\&D exp status 2009) and training activities (Training status 2009). As explained in Introduction and in Sect. 4, the literature suggests that these traits are associated with firm strategies conducive to

\footnotetext{
22 In fact, the presence of a board of directors is not significant in 2007/2008. This confirms the Chinese tradition of treating boards of directors as not very important, due to the constraints posed on their monitoring capacity in normal times (Wei and Ling 2015).
} 
higher growth rates. As the CPES does not contain information on these aspects for years before 2009, we assess these variables only for the GFC period. As expected, investment in $R \& D$ and training activities appear to be associated with higher firm growth. This is in line with the idea that companies that expand faster are investing in knowledge accumulation (Capasso et al. 2015; Garcia-Manjon and RomeroMerino 2012). Recent evidence provided by Zhu et al. (2021) suggests that this relationship is stable in time given that it has been detected also in the years following the GFC. The negative (insignificant) coefficient for exporting status that we found may seem counter-intuitive given the well-known extraordinary performance of the Chinese exporters. However, while Chinese exporting companies have grown more than purely domestic firms when the global demand was flourishing (Yang and Tsou 2020), they were also the most directly exposed to trade collapse during the GFC. ${ }^{23}$ Similar conclusions have been reached by Kolasa et al. (2010), who find that exportoriented Polish firms suffered the most, in terms of sales growth, from the contraction in global demand brought about by the GFC. Furthermore, as a check, we show that access to State subsidies (Subsidies status 2009) did not affect firm growth rates during the GFC. This finding is in line with the evidence that the Chinese authorities implemented a stimulus policy based on higher domestic demand and more abundant credit, and not on firm subsidies. As the variables capturing firm strategies are measured in 2009, they might be endogenous. Omitted unobserved factors could affect both growth rates and firms' strategies: the extent to which firms suffer financial constraints, for instance, may negatively impact both growth and the decision to invest in R\&D. Short of internal instruments and longitudinal variation, we cannot fully address these concerns. For this reason, we interpret these findings with caution and in terms of correlations.

The last set of results, reported in Table 5, includes various extensions of the specification (4) exploiting additional entrepreneur-level features. The first finding regards the role of the entrepreneur within the firm. We include a dummy variable CEOentrepreneur taking value 1 if the entrepreneur is also the CEO, and 0 otherwise. This covariate turns out to be statistically significant only in the estimations for the growth rate of sales during the GFC, with and without the variables capturing firm strategies. ${ }^{24}$ This result could be due to the fact that the direct engagement of the entrepreneur in the top management of the firm becomes important at the time of the crisis as he/she is in the position to align the firm's activities with the new business opportunities emerging during the crisis. One alternative possibility is that the entrepreneur-CEO can extract higher returns from personal ties with the officials in charge of implementing the Chinese stimulus plan. An alternative interpretation is that, as suggested by Joe et al. (2019), owner-managers have a superior ability to identify and pursue investment opportunities, especially in a volatile and changing

\footnotetext{
23 Moreover, exporting companies probably benefited less from the increase in domestic demand due to the stimulus package.

24 To make the results comparable across time, we reproduced the estimates both with and without the inclusion of the significant variables capturing the firm strategies (i.e., R\&D and traineeship expenditures) for the GFC period.
} 
Table 4 Firm growth covariates, during GFC_-2008/2009, extension

\begin{tabular}{|c|c|c|c|c|c|}
\hline & (1) & (2) & (3) & (4) & (5) \\
\hline In Sales $_{2007}$ & $\begin{array}{l}-15.17 * * * \\
(2.093)\end{array}$ & $\begin{array}{l}-17.62 * * * \\
(2.020)\end{array}$ & $\begin{array}{l}-16.25 * * * \\
(2.009)\end{array}$ & $\begin{array}{l}-15.19 * * * \\
(2.003)\end{array}$ & $\begin{array}{l}-18.46 * * * \\
(2.197)\end{array}$ \\
\hline ln capital at setup & $\begin{array}{l}3.620 * * * \\
(1.383)\end{array}$ & $\begin{array}{l}4.737 * * * \\
(1.316)\end{array}$ & $\begin{array}{l}4.037 * * * \\
(1.281)\end{array}$ & $\begin{array}{l}3.894 * * * \\
(1.305)\end{array}$ & $\begin{array}{l}5.049 * * * \\
(1.379)\end{array}$ \\
\hline AgeFirm & $\begin{array}{l}0.951 \\
(4.052)\end{array}$ & $\begin{array}{l}0.562 \\
(3.751)\end{array}$ & $\begin{array}{l}0.0592 \\
(3.881)\end{array}$ & $\begin{array}{l}0.224 \\
(3.945)\end{array}$ & $\begin{array}{l}2.047 \\
(3.903)\end{array}$ \\
\hline LabProd & $\begin{array}{l}24.28 * * * \\
(2.905)\end{array}$ & $\begin{array}{l}25.34 * * * \\
(2.832)\end{array}$ & $\begin{array}{l}23.62 * * * \\
(2.771)\end{array}$ & $\begin{array}{l}23.56^{* * * *} \\
(2.797)\end{array}$ & $\begin{array}{l}25.40 * * * \\
(2.987)\end{array}$ \\
\hline Gender & $\begin{array}{l}-1.476 \\
(5.262)\end{array}$ & $\begin{array}{l}-1.420 \\
(5.206)\end{array}$ & $\begin{array}{l}-1.641 \\
(4.981)\end{array}$ & $\begin{array}{l}-0.681 \\
(4.983)\end{array}$ & $\begin{array}{l}-4.623 \\
(5.458)\end{array}$ \\
\hline HighEucation & $\begin{array}{l}11.03 * * \\
(4.550)\end{array}$ & $\begin{array}{l}13.49 * * * \\
(3.502)\end{array}$ & $\begin{array}{l}9.683 * * \\
(4.261)\end{array}$ & $\begin{array}{l}9.967 * * \\
(4.211)\end{array}$ & $\begin{array}{l}13.13 * * * \\
(3.701)\end{array}$ \\
\hline AgeEntrepreneur & $\begin{array}{l}0.0590 \\
(0.210)\end{array}$ & $\begin{array}{l}0.151 \\
(0.220)\end{array}$ & $\begin{array}{l}0.0790 \\
(0.208)\end{array}$ & $\begin{array}{l}0.0823 \\
(0.209)\end{array}$ & $\begin{array}{l}0.0592 \\
(0.219)\end{array}$ \\
\hline Privatized & $\begin{array}{l}2.957 \\
(5.447)\end{array}$ & $\begin{array}{l}1.402 \\
(4.947)\end{array}$ & $\begin{array}{l}1.432 \\
(5.359)\end{array}$ & $\begin{array}{l}2.058 \\
(5.187)\end{array}$ & $\begin{array}{l}2.489 \\
(5.314)\end{array}$ \\
\hline Joint-stock company & $\begin{array}{l}10.51^{*} \\
(5.377)\end{array}$ & $\begin{array}{l}10.39 * * \\
(5.088)\end{array}$ & $\begin{array}{l}10.32 * * \\
(5.148)\end{array}$ & $\begin{array}{l}11.62 * * \\
(5.165)\end{array}$ & $\begin{array}{l}8.055 \\
(5.156)\end{array}$ \\
\hline Merged in 2008-2009 & $\begin{array}{l}14.23 \\
(11.27)\end{array}$ & $\begin{array}{l}17.70 * \\
(10.65)\end{array}$ & $\begin{array}{l}13.05 \\
(10.22)\end{array}$ & $\begin{array}{l}14.25 \\
(10.42)\end{array}$ & $\begin{array}{l}15.82 \\
(11.49)\end{array}$ \\
\hline Credit in setup fund & $\begin{array}{l}6.936^{*} \\
(4.200)\end{array}$ & $\begin{array}{l}7.360 * \\
(3.887)\end{array}$ & $\begin{array}{l}5.516 \\
(3.925)\end{array}$ & $\begin{array}{l}7.218^{*} \\
(3.961)\end{array}$ & $\begin{array}{l}5.027 \\
(4.077)\end{array}$ \\
\hline Board of directors & $\begin{array}{l}12.79 * * * \\
(4.040)\end{array}$ & $\begin{array}{l}10.58 * * * \\
(3.896)\end{array}$ & $\begin{array}{l}10.42 * * * \\
(3.702)\end{array}$ & $\begin{array}{l}10.28 * * * \\
(3.814)\end{array}$ & $\begin{array}{l}10.06 * * \\
(4.034)\end{array}$ \\
\hline Board of shareholders & $\begin{array}{l}7.045 * \\
(3.830)\end{array}$ & $\begin{array}{l}5.642 \\
(3.711)\end{array}$ & $\begin{array}{l}6.234 * \\
(3.598)\end{array}$ & $\begin{array}{l}7.117 * \\
(3.696)\end{array}$ & $\begin{array}{l}7.124 * \\
(3.836)\end{array}$ \\
\hline Export status 09 & $\begin{array}{l}-2.520 \\
(3.537)\end{array}$ & & & & $\begin{array}{l}-3.739 \\
(3.749)\end{array}$ \\
\hline R\&D exp status 09 & & $\begin{array}{l}11.60 * * * \\
(3.659)\end{array}$ & & & $\begin{array}{l}8.402 * \\
(4.404)\end{array}$ \\
\hline Traineeship status 09 & & & $\begin{array}{l}13.06 * * * \\
(4.062)\end{array}$ & & $\begin{array}{l}12.54 * * * \\
(4.641)\end{array}$ \\
\hline Subsidies stratus 09 & & & & $\begin{array}{l}4.814 \\
(3.701)\end{array}$ & $\begin{array}{l}3.042 \\
(4.030)\end{array}$ \\
\hline Industry FE & YES & YES & YES & YES & YES \\
\hline Province FE & YES & YES & YES & YES & YES \\
\hline Observations & 2348 & 2373 & 2498 & 2486 & 2182 \\
\hline Adjusted $R^{2}$ & 0.109 & 0.126 & 0.112 & 0.107 & 0.126 \\
\hline
\end{tabular}

Independent variable: growth rate of sales in 2008/2009. Covariates regarding firm strategy in 2009: export status dummy, R\&D expenditure status dummy, traineeship activities status dummy, subsidies recipient dummy. Results show the coefficients with heteroskedasticity-robust standard errors (in parenthesis): ${ }^{*}<0.1,{ }^{* *}<0.05,{ }^{* * *}<0.01$ 


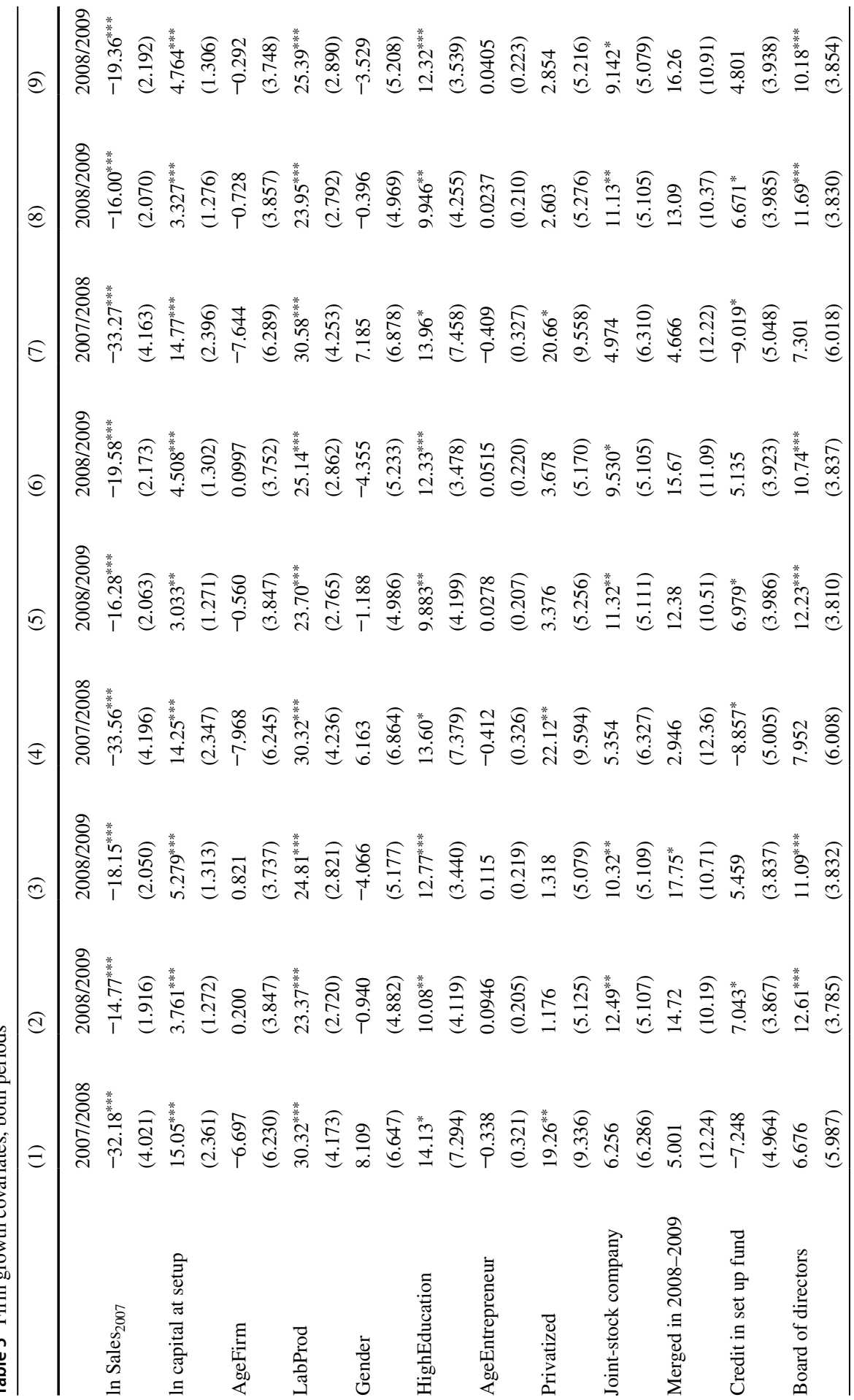




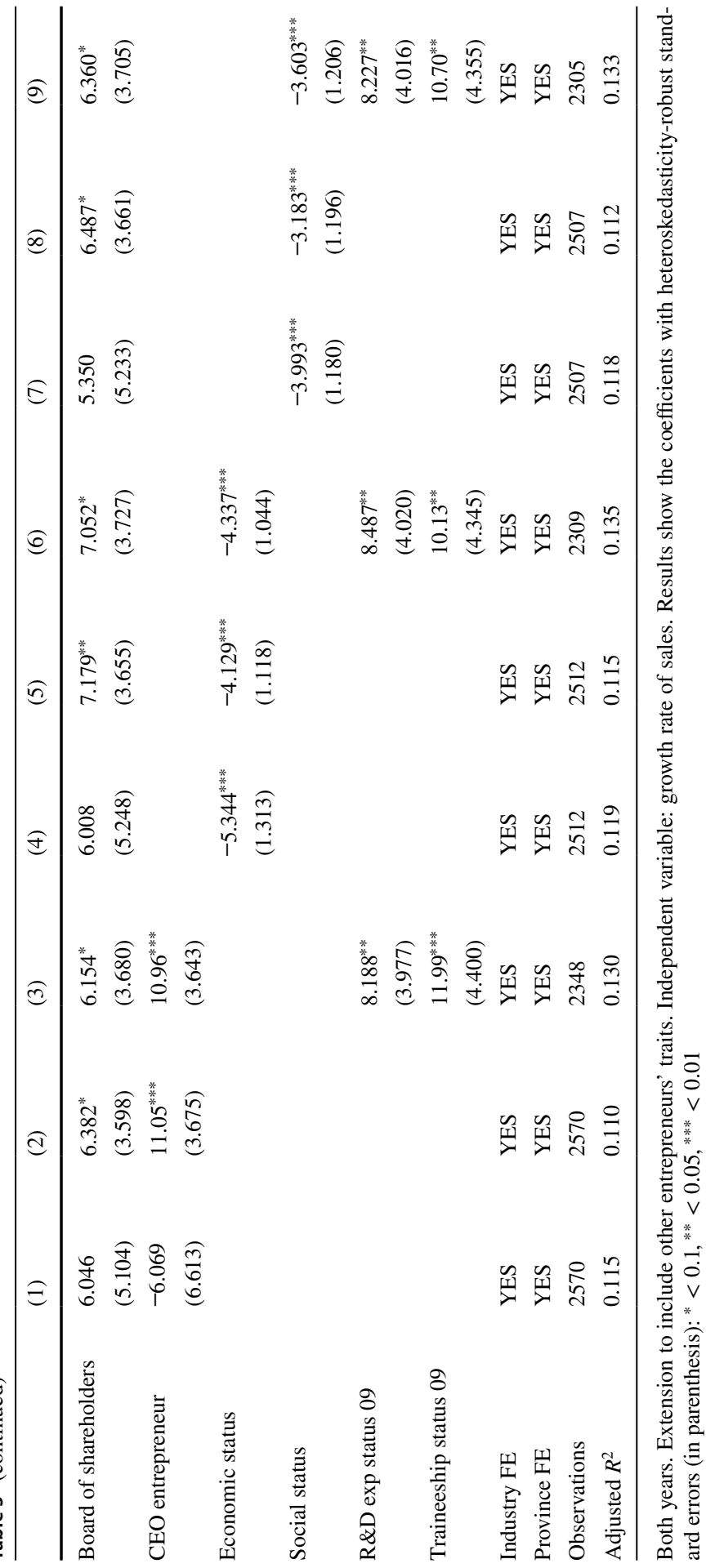


environment, such as a crisis. Interestingly, these results disagree with those in Bartz and Winkler (2016), who find that German firms whose director is the founder outperformed the others in normal periods, but not during the GFC.

Finally, we explore the impact of the assessment that the entrepreneurs give of their own economic and social status on firm growth in the period 2008/2009. We expect a positive correlation between the entrepreneur's subjective evaluation of the status and the firm's performance for the various reasons discussed in Sect. 2. The estimates confirm that this is indeed the case. Given that the variables go from 1 (highest relative position) to 10 (lowest relative position), negative coefficients are in line with our expectations of a positive relationship between perceived status and firm growth. As anticipated, there are multiple interpretations of these results. Assuming that the entrepreneur's self-perception is correct, one way to interpret the estimates is that the qualities of the entrepreneur are, so to speak, transferred to the firm: for instance, entrepreneurs with high social status may have better connections and enjoy greater credibility, and these traits may provide an advantage to their firms, especially in difficult periods such as a credit crunch. This reading of the impact of perceived social status is consistent with what was reported by Chen and Zhang (2017) on charitable giving, whereby the perceived status of entrepreneurs is connected with the giving behavior of their private companies. Similarly, Liu et al. (2021) show that Chinese entrepreneurs with high social status are more prone to make their firms engage in social responsibility efforts. If we assume that the subjective evaluation of status is a proxy for the entrepreneur's self-esteem and optimism, our results could imply that companies run by optimistic and risk-loving entrepreneurs tend to grow more in China, as also suggested by Cucculelli and Ermini (2013). Finally, it is possible to explain our findings in terms of assortative-matching: the entrepreneurs working in successful companies may have rosier perceptions of their own status in the society, and firms with higher potential may attract entrepreneurs with higher social status. This interpretation is particularly relevant for the perceived economic status. Notably, the inclusion of these variables does not significantly modify the estimated coefficients for all the other individual features in the baseline specification.

\section{Conclusions, limitations and policy implications}

In this work we exploited the peculiar characteristics of the 2010 wave of the CPES to explore how firm- and entrepreneur-specific attributes covariate with Chinese private firms' growth rates in the period 2007-2009. Building on a representative sample of entrepreneurs, we found novel results on the relationship between firm performance and various firms' and entrepreneurs' features, which we identified as potential drivers of firm growth in previous theoretical and empirical studies. We show that, as pointed out by Bartz and Winkler (2016) in a study on German firms during the GFC, "crisis times are associated with a rise in uncertainty where patterns observed in normal times do not hold." The relationship between some of the 
covariates and the firm growth rates does also significantly change in China after the GFC.

Our estimations confirm a number of results from previous analyses, and, in particular, the usual relationships between firm size and productivity, on the one hand, and the growth rates, on the other. The companies with better access to external financing, moreover, seem to have performed better during the crisis period, in line with the evidence on the importance of credit constraints for small private companies in China. In contrast with works focusing on other countries, this analysis suggests that the age of the company and the gender of the entrepreneur are immaterial for what concerns the performance of the firms in either period. Moreover, the estimates suggest that only the education of the entrepreneur positively influences the growth of the firm and to a similar extent in both periods. The age of the entrepreneur, instead, does not seem a significant determinant of growth differentials. We interpret these results as suggestive of education over age, probably because age and previous experiences are not necessarily conducive to better entrepreneurial outcomes in the early stages of the Chinese transition toward a market-oriented economy.

The creation of variables measuring the entrepreneurs' perception of their economic and social status allows us to find another a novel result: the companies run by the entrepreneurs with a high perceived economic and social status tend to grow more. While this may be due to assortative matching between firms and entrepreneurs, it is possible that the entrepreneur's reputation represents a valuable intangible asset for the company. Different levels of self-esteem, moreover, may be associated with different business practices, in turn conducive to diverse outcomes. Unsurprisingly, the firms where the entrepreneur/founder takes the role of CEO tend to grow more during the GFC, perhaps because this is exactly when personal connections help to access scarce resources and increase domestic market shares. We also find the companies with a board of directors and/or a board of shareholders perform better during the crisis period, as do also the joint-stock companies. These results taken together suggest that private firms in China weathered the GFC better when they could count on articulated solutions of corporate governance (whereby more people could contribute to sharing information and connections), on closer ties with large international firms (that could smooth the impact of the crisis) and on well-educated, high status entrepreneurs who were fully engaged in the management of the companies.

As to the firms' strategies, the Chinese private companies that engaged in knowledge accumulation appear to have outperformed the others during the crisis, whereas exporting companies suffered relatively more from the sharp collapse in global demand.

Finally, the performance of the private companies in China in this period appears to be influenced by whether or not the experiences, resources, organizational solutions, strategies and business practices they could rely upon matched what was required, given the mutable economic conditions associated with the GFC. This finding strengthens our intuition that the entrepreneurs' traits and the companies' 
characteristics contribute to explain the highly heterogeneous performance of the Chinese firms both in normal and in critical periods.

Admittedly, our analysis has several limitations. Notwithstanding the adoption of two cross-sections for the same sample of companies, the characteristics of the CPES prevent us from pooling waves of the survey and from carrying out a longitudinal study. ${ }^{25}$ The inclusion of several firm-level covariates, the use of lagged values and the introduction of industry and provincial fixed effects limit the possible endogeneity problems associated with certain variables. Since the results of the baseline specification do not change when we introduce the covariates one at a time or simultaneously, omitted variable problems might be of limited relevance. Notwithstanding, the cross-sectional nature of the CPES demands great caution in the interpretation of the estimates. This is, indeed, the reason why we discussed the results most often in terms of statistical associations rather than causal relationships between the covariates and the firm growth rates. Despite these limitations stemming from the cross-sectional nature of the CPES, it is important to stress that both the number of firms in the survey and the representativeness of the CPES sample are precious, and they allow us to draw evidence on firms and entrepreneurs in China that would otherwise not be available in other longitudinal dataset. The CPES, hence, remains a valuable source of information compared with other small and ad hoc surveys on entrepreneurs' characteristics, as it guarantees a much wider coverage of Chinese cities and private firms of any size than other similar surveys.

A second limitation of our study regards the decision of delineating the variation between 2007 and 2008 as pre-GFC period and that between 2008 and 2009 as GFC period. This is an approximation because the GFC started in mid-September 2008, and it affected firms' sales in the last quarter of 2008. Although this approximation has to be acknowledged for the sake of precision, it appears a conservative choice because the differences in the firms' growth rates across the two periods would have been potentially larger, had the GFC started in January 2009. Detecting significant differences across the two periods, thus, is made more difficult by this approximation. For analogous reasons, a similar approach has been adopted also by other researchers interested in the impact of the GFC (see Lin and Chou 2015; Joe et al. 2019; Cong et al. 2019; Kolasa et al. 2010, among others).

A third limitation is associated with the partial overlap between the GFC and the Chinese stimulus plan. Admittedly, due to the lack of firm-level information about the plan, we could not distinguish the relative impact of these two phenomena on the firms' performances in the second period. We took this into account in the interpretation of the results where possible.

Our analysis allows us to draw a few methodological suggestions. Our findings cast some doubt on the robustness of the results obtained by pooling cross-sectional

\footnotetext{
25 It is worth recalling that pooling several waves would have not allowed us to address the change in the parameters around the GFC. The sample of entrepreneurs and firms involved in one CPES wave radically varies over the two consecutive surveys. This prevents us from performing a longitudinal analysis. Merging the CPES with the Chinese annual Survey of Industrial Production would not have been possible either, as the overlap between the samples of the two surveys is very limited.
} 
waves of the CPES, as is often done in the literature. Pooling waves increases the sample size and allows to exploit the variation of some variables over time, but it is not warranted in the presence of a structural break. In our analysis, this is relevant for the estimated impact of several, though not all, variables. In other words, pooling CPES waves is possible and useful, but some care is warranted in the presence of major economic disruptions.

To close, we would like to draw some policy implications from our analysis. The first implication regards the importance of appreciating the role that individual attributes play in shaping the performance of firms in normal and critical periods. This implies, for instance, that the authorities should continue to support the education of entrepreneurs and the entrepreneurship of educated young people. Although the companies where the entrepreneurs are more involved in management perform better in difficult periods, so do those with a more sophisticated corporate model, whereby a number of different people may contribute to sharing information, to assessing the opportunity space and to activating social networks. Given that, as pointed out by Molnar et al. (2017), there are no tight governance rules for nonlisted non-State firms in China that are free to have boards or not, some improvements along this line may produce positive results.

Acknowledgements The authors are grateful to the Editor, Professor George Hondroyiannis, and to an anonymous reviewer for helpful comments and suggestions. Usual disclaimers apply.

Funding Open access funding provided by Università degli Studi di Trento within the CRUI-CARE Agreement.

Open Access This article is licensed under a Creative Commons Attribution 4.0 International License, which permits use, sharing, adaptation, distribution and reproduction in any medium or format, as long as you give appropriate credit to the original author(s) and the source, provide a link to the Creative Commons licence, and indicate if changes were made. The images or other third party material in this article are included in the article's Creative Commons licence, unless indicated otherwise in a credit line to the material. If material is not included in the article's Creative Commons licence and your intended use is not permitted by statutory regulation or exceeds the permitted use, you will need to obtain permission directly from the copyright holder. To view a copy of this licence, visit http://creativecommons.org/licen ses/by/4.0/.

\section{References}

Ahlstrom D, Ding Z (2014) Entrepreneurship in China: an overview. Int Small Bus J 32(6):610-618

Arkolakis C, Papageorgiou T, Timoshenko OA (2018) Firm learning and growth. Rev Econ Dyn 27:146-168

Audretsch DB, Coad A, Segarr A (2014) Firm growth and innovation. Small Bus Econ 43:743-749

Bai Ce, Hsieh CT, Song ZM (2016) The long shadow of China's fiscal expansion. Brookings Papers on Economic Activity 2:129-181

Bandura A (1997) Self-efficacy: the exercise of control. Freeman, New York

Barba Navaretti G, Castellani D, Pieri F (2014) Age and firm growth: evidence from three European countries. Small Bus Econ 43(4):823-837

Barbosa N, Eiriz V (2011) Regional variation of firm size and growth: the Portuguese case. Growth Change 42(2):125-158

Bartz W, Winkler A (2016) Flexible or fragile? The growth performance of small and young businesses during the global financial crisis: evidence from Germany. J Bus Ventur 31(2):196-215 
Baum JR, Locke EA (2004) The relationship of entrepreneurial traits, skill, and motivation to new venture growth. J Appl Psychol 587-598

Benini R, Liping H (2013) Special issue on China: re-thinking China's economic transition and development in the post-crisis era. Econ Change Restruct 46(1):1-7

Bin P, Chen X, Fracasso A, Tomasi C (2018) Resource allocation and productivity across provinces in China. Int Rev Econ Finance 57:103-113

Bin P, Chen X, Fracasso A, Tomasi C (2020) Firm employment growth in China: the role of marketization and regional economic factors. Growth Change 51:402-439

Bonatti L, Fracasso A (2010) Global rebalancing and the future of the Sino-US co-dependency. China World Econ 18(4):70-87

Bonatti L, Fracasso A (2013) Hoarding of international reserves in China: Mercantilism, domestic consumption and US monetary policy. J Int Money Finance 32(C):1044-1078

Botta M (2020) Financial crises, debt overhang, and firm growth in transition economies. Appl Econ 52:1-18

Boudreaux CJ, Nikolaev BN, Klein P (2019) Socio-cognitive traits and entrepreneurship: the moderating role of economic institutions. J Bus Ventur 34(1):178-196

Brandt L, Van Biesebroeck J, Zhang Y (2012) Creative accounting or creative destruction? Firm-level productivity growth in Chinese manufacturing. J Dev Econ 97(2):339-351

Buratti A, Cesaroni FM, Sentuti A (2018) Does gender matter in strategies adopted to face the economic crisis? A comparison between men and women entrepreneurs. In: Mura L (ed) Entrepreneurship: development tendencies and empirical approach. Intech Open

Cai F, Wang D, Zhang H (2010) Employment effectiveness of China's economic stimulus package. China World Econ 18(1):33-46

Caliendo M, Fossen F, Kritikos A (2014) Personality characteristics and the decisions to become and stay self-employed. Small Bus Econ 42(4):787-814

Campello M, Graham JR, Harvey CR (2010) The real effects of financial constraints: evidence from a financial crisis. J Financ Econ 97(3):470-487

Capasso M, Treibich T, Verspagen B (2015) The medium-term effect of R\&D on firm growth. Small Bus Econ 45(1):39-62

Carpenter R, Petersen B (2002) Is the growth of small firms constrained by internal finance? Rev Econ Stat 84(2):298-309

Cassar G (2004) The financing of business start-ups. J Bus Ventur 19(2):261-283

Chen G, Firth M, Xu L (2009) Does the type of ownership control matter? evidence from China's listed companies. J Bank Finance 33(1):171-181

Chen G, Lu P, Lin Z, Song N (2019) Introducing Chinese private enterprise survey: points and prospects. Nankai Bus Rev Int 10(4):501-523

Chen S, Jefferson GH, Zhang J (2011) Structural change, productivity growth and industrial transformation in China. China Econ Rev 22(1):133-150

Chen Z, Zhang J (2017) Status incentives and corporate giving: evidence from China's political reform on private enterprises. Pac Econ Rev 22(5):841-860

Chong TTL, Lu L, Ongena S (2013) Does banking competition alleviate or worsen credit constraints faced by small- and medium-sized enterprises? Evidence from China. J Bank Finance 37(9):3412-3424

Cieslik J, Kaciak E, Stel AV (2018) Country-level determinants and consequences of overconfidence in the ambitious entrepreneurship segment. Int Small Bus J Resear Entrep 36(5):473-499

Clarke GR, Cull R, Kisunko G (2012) External finance and firm survival in the aftermath of the crisis: evidence from eastern Europe and central Asia. J Comp Econ 40(3):372-392

Coad A (2009) The growth of firms: a survey of theories and empirical evidence. Edward Elgar Publishing

Coad A (2018) Firm age: a survey. J Evolut Econ 28:13-43

Coad A, Holzl W (2012) Firm growth: empirical analysis. In: Dietrich M, and Krafft J (eds) Handbook on the economics and theory of the firm, Edward Elgar Publishing, chap 24

Coad A, Rao R (2008) Innovation and firm growth in high-tech sectors: a quantile regression approach. Res Policy 37(4):633-648

Coad A, Segarra A, Teruel M (2016) Innovation and firm growth: does firm age play a role? Res Policy 45(2):387-400

Colombo MG, Grilli L (2010) On growth drivers of high-tech start-ups: exploring the role of founders' human capital and venture capital. J Bus Ventur 25(6):610-626 
Cong LW, Gao H, Ponticelli J, Yang X (2019) Credit allocation under economic stimulus: evidence from China. Rev Financ Stud 32(9):3412-3460

Cowling M, Liu W, Ledger A (2012) Small business financing in the UK before and during the current financial crisis. Int Small Bus J 30(7):778-800

Cowling M, Liu W, Ledger A, Zhang N (2015) What really happens to small and medium-sized enterprises in a global economic recession? UK evidence on sales and job dynamics. Int Small Bus $\mathbf{J}$ 33(5):488-513

Cowling M, Liu W, Zhang N (2018) Did firm age, experience, and access to finance count? SME performance after the global financial crisis. J Evolut Econ 28:77-100

Cucculelli M, Ermini B (2013) Risk attitude, product innovation, and firm growth. evidence from Italian manufacturing firms. Econ Lett 118(2):275-279

Cumming DJ, Guariglia A, Hou W, Lee E (2016) Special issue: history and evolution of entrepreneurship and finance in China. Bus Hist 58(3):317-318

Curtis CC (2016) Economic reforms and the evolution of China's total factor productivity. Rev Econ Dyn 21:225-245

Daunfeldt SO, Elert N (2013) When is Gibrat's law a law? Small Bus Econ 41(1):133-147

Degryse H, Lu L, Ongena S (2016) Informal or formal financing? Evidence on the co-funding of Chinese firms. J Financ Intermed 27(C):31-50

Deschryvere M (2014) R\&D, firm growth and the role of innovation persistence: an analysis of finish SMEs and large firms. Small Bus Econ 43(4):767-785

Di Cintio M, Ghosh S, Grassi E (2017) Firm growth, R\&D expenditures and exports: an empirical analysis of Italian SMEs. Res Policy 46(4):836-852

Ding S, Guariglia A, Harris R (2016) The determinants of productivity in Chinese large and mediumsized industrial firms, 1998-2007. J Prod Anal 45(2):131-155

Djankov S, Qian Y, Roland G, Zhuravskaya E (2006) Who are China's entrepreneurs? Am Econ Rev 96(2):348-352

Dong Z, Wei X, Zhang Y (2016) The allocation of entrepreneurial efforts in a rent-seeking society: evidence from China. J Comp Econ 44(2):353-371

Du J, Lu Y, Tao Z (2015) Government expropriation and Chinese-style firm diversification. J Comp Econ 43(1):155-169

Elston JA, Weidinger A (2019) Entrepreneurial intention and regional internationalization in China. Small Bus Econ 53:1001-1015

Elston JA, Chen S, Weidinger A (2016) The role of informal capital on new venture formation and growth in China. Small Bus Econ 46(1):79-91

Fairlie R, Robb A (2009) Gender differences in business performance: evidence from the characteristics of business owners survey. Small Bus Econ 33(4):375-395

Fan G, He L, Wei X, Han L (2013) China's growth adjustment: moderation and structural changes. Econ Change Restruct 46(1):9-24

Fort TC, Haltiwanger J, Jarmin RS, Miranda J (2013) How firms respond to business cycles: the role of firm age and firm size. IMF Econ Rev 61(3):520-559

Frank H, Lueger M, Korunka C (2007) The significance of personality in business start-up intentions, start-up realization and business success. Entrep Reg Develop 19(3):227-251

Freel M (2000) Do small innovating firms outperform non-innovators? Small Bus Econ 14:195-210

Freel MS, Robson PJA (2004) Small firm innovation, growth and performance: evidence from Scotland and northern England. Int Small Bus J 22(6):561-575

Garcia-Manjon JV, Romero-Merino ME (2012) Research, development, and firm growth. Empirical evidence from European top R\&D spending firms. Res Policy 41(6):1084-1092

Ge J, Stanley LJ, Eddleston K, Kellermanns FW (2017) Institutional deterioration and entrepreneurial investment: the role of political connections. J Bus Ventur 32(4):405-419

George G, Dahlander L, Graffin SD, Sim S (2016) Reputation and status: expanding the role of social evaluations in management research. Acad Manag J 59(1):1-13

Geroski P, Machin S (1992) Do innovating firms outperform non-innovators?. Bus Strat Rev 3(2):79-90

Gibrat R (1931) Les inégalités économiques. Librairie du Recueil Sirey, Paris

Gielnik MM, Zacher H, Frese M (2012) Focus on opportunities as a mediator of the relationship between business owners' age and venture growth. J Bus Ventur 27(1):127-142

Gielnik MM, Zacher H, Schmitt A (2017) How small business managers' age and focus on opportunities affect business growth: a mediated moderation growth model. J Small Bus Manag 55(3):460-483 
Goedhuys M, Sleuwaegen L (2000) Entrepreneurship and growth of entrepreneurial firms in Cote d'Ivoire. J Dev Stud 36(3):123-145

Goedhuys M, Sleuwaegen L (2010) High-growth entrepreneurial firms in Africa: a quantile regression approach. Small Bus Econ 34(1):31-51

Grazzi M, Moschella D (2018) Small, young, and exporters: new evidence on the determinants of firm growth. J Evolut Econ 28(1):125-152

Guariglia A, Liu X, Song L (2011) Internal finance and growth: microeconometric evidence on Chinese firms. J Dev Econ 96(1):79-94

Guo D, Jiang K, Kim BY, Xu C (2014) Political economy of private firms in China. J Comp Econ 42(2):286-303

Haltiwanger J, Jarmin RS, Miranda J (2013) Who creates jobs? Small versus large versus young. Rev Econ Stat 95(2):347-361

Hambrick DC, Mason PA (1984) Upper echelons: the organization as a reflection of its top managers. Acad Manag Rev 9(2):193-206

He C, Lu J, Qian H (2019) Entrepreneurship in China. Small Bus Econ 52:563-572

He Y, ho Chiu Y, Zhang B (2015) The impact of corporate governance on state-owned and non-stateowned firms efficiency in China. N Am J Econ Finance 33:252-277

Hericourt J, Poncet S (2009) FDI and credit constraints: firm-level evidence from China. Econ Syst 33(1):1-21

Hirshleifer D, Low A, Teoh SH (2012) Are overconfident CEOs better innovators? J Finance 67(4):1457-1498

Hölzl W (2009) Is the R\&D behaviour of fast-growing SMEs different? Evidence from CIS III data for 16 countries. Small Bus Econ 33(1):59-75

Honjo Y (2021) The impact of founders' human capital on initial capital structure. Technov 100, 102191

Huynh KP, Petrunia RJ (2010) Age effects, leverage and firm growth. J Econ Dyn Control 34(5):1003-1013

Ipinnaiye O, Dineen D, Lenihan H (2017) Drivers of SME performance: a holistic and multivariate approach. Small Bus Econ 48(4):883-911

Iwasaki I (2014) Global financial crisis, corporate governance, and firm survival. J Comp Econ 42(1):178-211

Joe YD, Jung D, Oh FD (2019) Owner-managers and firm performance during the Asian and global financial crises: evidence from Korea. Appl Econ 51(6):611-623

Joeveer K (2013) What do we know about the capital structure of small firms? Small Bus Econ 41(2):479-501

Judge T., Bono JE (2001) Relationship of core self-evaluations traits-self-esteem, generalized self-efficacy, locus of control, and emotional stability-with job satisfaction and job performance: a metaanalysis. J Appl Psychol 86(1):80-92

Kerr SP, Kerr WR, Xu T (2017) Personality traits of entrepreneurs: a review of recent literature. NBER Working Papers 24097, National Bureau of Economic Research, Inc

Kolasa M, Rubaszek M, Taglioni D (2010) Firms in the great global recession: the role of foreign ownership and financial dependence. Emerg Mark Rev 11(4):341-357

Koryak O, Mole KF, Lockett A, Hayton JC, Ucbasaran D, Hodgkinson GP (2015) Entrepreneurial leadership, capabilities and firm growth. Int Small Bus J 33(1):89-105

Kung JK, and Lin Y-M (2007) The decline of township-and-village enterprises in China's economic transition. World Dev 35(4):569-584

Lardy N (2011) Sustaining China's economic growth after the global financial crisis. Columbia University Press, Columbia

Lawless M (2014) Age or size? Contributions to job creation. Small Bus Econ 42:815-830

Lee I, Marvel M (2014) Revisiting the entrepreneur gender-performance relationship: a firm perspective. Small Bus Econ 42(4):769-786

Leoncini R, Marzucchi A, Montresor S, Rentocchini F, Rizzo U (2019) 'Better late than never': the interplay between green technology and age for firm growth. Small Bus Econ 52:891-904

Li H, Meng L, Wang Q, Zhou LA (2008) Political connections, financing and firm performance: evidence from Chinese private firms. J Dev Econ 87(2):283-299

Lin TT, Chou JH (2015) Trade credit and bank loan: evidence from Chinese firms. Int Rev Econ Finance 36:17-29

Liu Q, Lu R, Zhang C (2014) Entrepreneurship and spillovers from multinationals: evidence from Chinese private firms. China Econ Rev 29:95-106 
Liu Y, Dai W, Liao M, Wei J (2021) Social status and corporate social responsibility: evidence from Chinese privately owned firms. J Bus Ethics 169: 651-672

Lu L, Wu Y (2020) Does religion enhance firm performance? Evidence from private firms in China. China Econ Rev 62: 101480

Lu Y, Tao Z (2009) Contract enforcement and family control of business: evidence from China. J Comp Econ 37(4):597-609

Ma G, Rui OM, Wu Y (2015) A springboard into politics: do Chinese entrepreneurs benefit from joining the government-controlled business associations? China Econ Rev 36:166-183

Marquis C, Qiao K (2020) Waking from mao's dream: communist ideological imprinting and the internationalization of entrepreneurial ventures in China. Adm Sci Q 65(3):795-830

Marvel MR, Davis JL, Sproul CR (2016) Human capital and entrepreneurship research: a critical review and future directions. Entrep Theory Pract 40(3):599-626

Mathias BD, Williams DW, Smith AR (2015) Entrepreneurial inception: the role of imprinting in entrepreneurial action. J Bus Ventur 30(1):11-28

McMillan J, Woodruff C (2002) The central role of entrepreneurs in transition economies. J Econ Persp 16(3):153-170

Miao C, Qian S, Ma D (2017) The relationship between entrepreneurial self-efficacy and firm performance: a meta-analysis of main and moderator effects. J Small Bus Manag 55(1):87-107

Milanov H, Fernhaber SA (2009) The impact of early imprinting on the evolution of new venture networks. J Bus Ventur 24(1):46-61

Molnar M, Wang B, Chen W (2017) Corporate governance and firm performance in China. OECD Economics Department Working Papers 1421, OECD Publishing

Moscarini G, Postel-Vinay F (2012) The contribution of large and small employers to job creation in times of high and low unemployment. Am Econ Rev 102(6):2509-2539

Moschella D, Tamagni F, Yu X (2019) Persistent high-growth firms in China's manufacturing. Small Bus Econ 52(3):573-594

Musso P, Schiavo S (2008) The impact of financial constraints on firm survival and growth. J Evolut Econ 18(2):135-149

Neumark D, Wall B, Zhang J (2011) Do small businesses create more jobs? New evidence for the United States from the national establishment time series. Rev Econ Stat 93(1):16-29

Nunes PM, Gonçalves M, Serrasqueiro Z (2013) The influence of age on SMES' growth determinants: empirical evidence. Small Bus Econ 40(2):249-272

Peric M, Vitezic V (2016) Impact of global economic crisis on firm growth. Small Bus Econ 46(1):1-12

Poggesi S, Mari M, Vita L (2016) What's new in female entrepreneurship research? Answers from the literature. Int Entrep Manag J 12(3):735-764

Poncet S, Steingress W, Vandenbussche H (2010) Financial constraints in China: firm-level evidence. China Econ Rev 21(3):411-422

Poon JML, Ainuddin RA, Junit SH (2006) Effects of self-concept traits and entrepreneurial orientation on firm performance. Int Small Bus J 24(1):61-82

Rauch A, Frese M (2007) Let's put the person back into entrepreneurship research: a meta-analysis on the relationship between business owners' personality traits, business creation, and success. Eur J Work Org Psychol 16(4):353-385

Saridakis G (2012) Introduction to the special issue on enterprise activity, performance and policy during times of crisis. Int Small Bus J 30(7):733

Shi X, Wu Y (2017) The effect of internal and external factors on innovative behaviour of Chinese manufacturing firms. China Econ Rev 46(Supplement):S50-S64

Smallbone D, Deakins D, Battisti M, Kitching J (2012) Small business responses to a major economic downturn: empirical perspectives from New Zealand and the United Kingdom. Int Small Bus J 30(7):754-777

Song Z, Storesletten K, Zilibotti F (2011) Growing like china. Am Econ Rev 101(1):196-233

Sousa N, Rueda-Cantuche JM, Arto I, Andreoni V (2012) Extra-EU exports and employment. DG TRADE Chief Economist Notes 2012-2, Directorate General for Trade, European Commission

Unger JM, Rauch A, Frese M, Rosenbusch N (2011) Human capital and entrepreneurial success: a meta-analytical review. J Bus Ventur 26(3):341-358

Vivarelli M (2013) Is entrepreneurship necessarily good? Microeconomic evidence from developed and developing countries. Ind Corp Change 22(6):1453-1495 
Vivarelli M (2016) The middle income trap: a way out based on technological and structural change. Econ Change Restruct 49:159-193

Wei LQ, Ling Y (2015) CEO characteristics and corporate entrepreneurship in transition economies: evidence from China. J Bus Res 68(6):1157-1165

Wen Y, Wu J (2019) Withstanding the great recession like China. Manchester School 87(2):138-182

Wennberg K, Pathak S, Autio E (2013) How culture moulds the effects of self-efficacy and fear of failure on entrepreneurship. Entrep Reg Develop 25(9-10):756-780

Wong C (2011) The fiscal stimulus programme and public governance issues in China. OECD J Budg 11:3

Yang CH, Tsou MW (2020) Globalization and firm growth: does ownership matter? Small Bus Econ 55(4):1019-1037

Yu X, Dosi G, Grazzi M, Lei J (2017) Inside the virtuous circle between productivity, profitability, investment and corporate growth: an anatomy of Chinese industrialization. Res Policy 46(5): 1020-1038

Yueh L (2009) China's entrepreneurs. World Dev 37(4):778-786

Yusuf S, Nabeshima K, Perkins D.H. (2005) Under new ownership: : Privatizing China's State-Owned Enterprises. Washington, DC: World Bank and Stanford University Press

Zhang C (2017) Top manager characteristics, agglomeration economies and firm performance. Small Bus Econ 48:543-558

Zhang SX, Cueto J (2017) The study of bias in entrepreneurship. Entrep Theory Pract 41(3):419-454

Zhao H, Lu J (2016) Contingent value of political capital in bank loan acquisition: evidence from founder-controlled private enterprises in China. J Bus Ventur 31(2):153-174

Zhao H, Seibert SE, Lumpkin G (2010) The relationship of personality to entrepreneurial intentions and performance: a meta-analytic review. J Manag 36(2):381-404

Zhao H, O'Connor G, Wu J, Lumpkin G (2021) Age and entrepreneurial career success: a review and a meta-analysis. J Bus Vent. forthcoming

Zheng J, Bigsten A, Hu A (2009) Can China's growth be sustained? A productivity perspective. World Develop 37(4):874-888

Zheng L, Zhao Z (2017) What drives spatial clusters of entrepreneurship in China? Evidence from economic census data. China Econ Rev 46:229-248

Zhou W (2013) Political connections and entrepreneurial investment: evidence from China's transition economy. J Bus Ventur 28(2):299-315

Zhu H, Zhang Z, Huang Y, Mao W (2021) Quantile heterogeneous impact of R\&D on firm growth in Chinese manufacture: how ownership, firm size and sectors matter? Appl Econ forthcoming

Zhu S, He C, Luo Q (2019) Good neighbors, bad neighbors: local knowledge spillovers, regional institutions and firm performance in China. Small Bus Econ 52(3):617-632

Publisher's Note Springer Nature remains neutral with regard to jurisdictional claims in published maps and institutional affiliations. 